Geochemical and Mineralogical Characterization of the Abandoned Valzinco (Lead-Zinc) and Mitchell (Gold) Mine Sites Prior to Reclamation, Spotsylvania County, Virginia

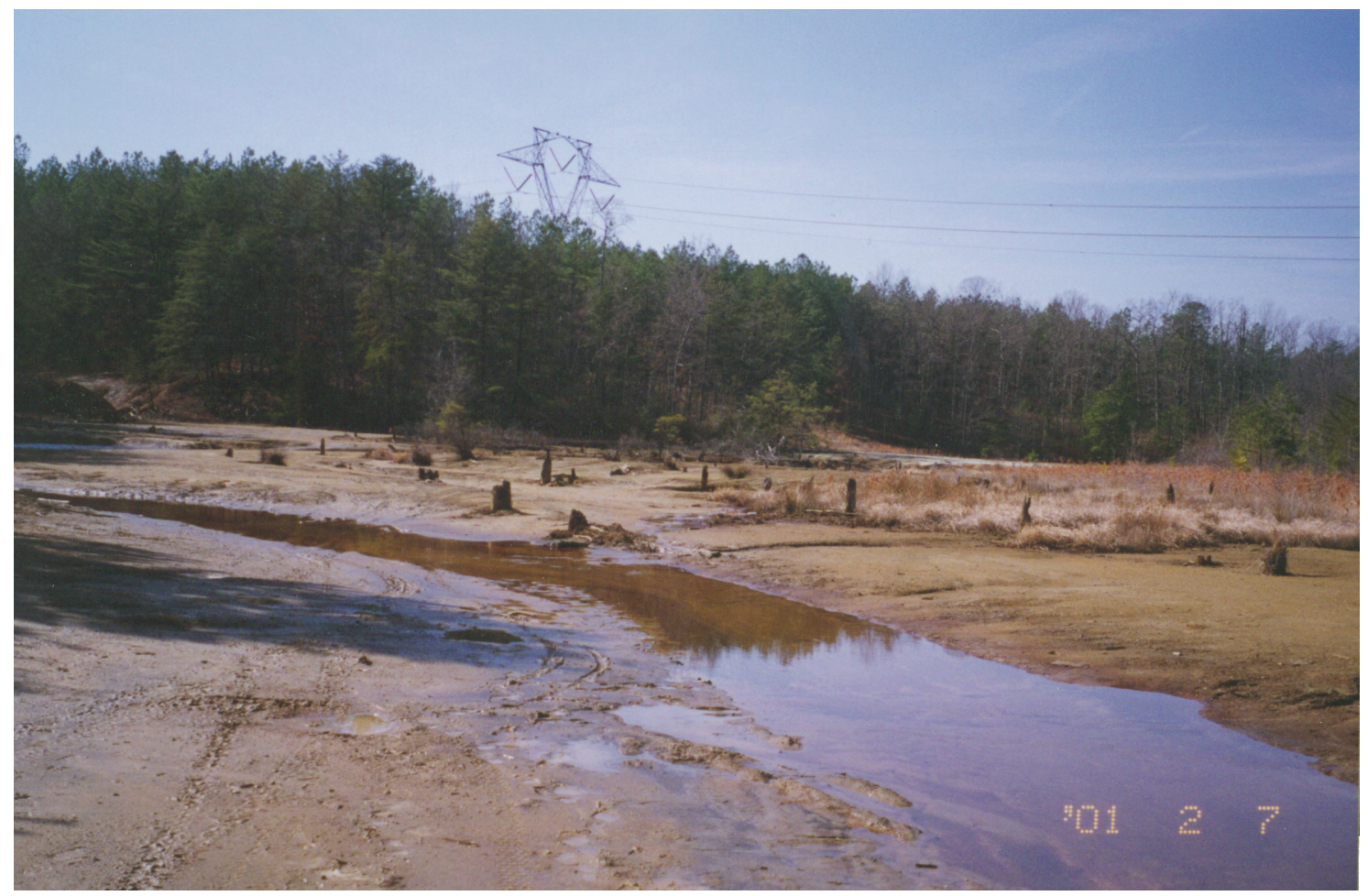

Scientific Investigations Report 2006-5085 


\section{Geochemical and Mineralogical Characterization of the Abandoned Valzinco (Lead-Zinc) and Mitchell (Gold) Mine Sites Prior to Reclamation, Spotsylvania County, Virginia}

By Jane M. Hammarstrom, Adam N. Johnson, Robert R. Seal II, Allen L. Meier, Paul L. Briggs, and Nadine M. Piatak

Prepared in cooperation with the Virginia Department of Mines, Minerals, and Energy

Scientific Investigations Report 2006-5085 


\section{U.S. Department of the Interior \\ P. Lynn Scarlett, Acting Secretary}

\section{U.S. Geological Survey \\ P. Patrick Leahy, Acting Director}

\section{U.S. Geological Survey, Reston, Virginia: 2006}

For product and ordering information:

World Wide Web: http://www.usgs.gov/pubprod

Telephone: 1-888-ASK-USGS

For more information on the USGS--the Federal source for science about the Earth, its natural and living resources, natural hazards, and the environment:

World Wide Web: http://www.usgs.gov

Telephone: 1-888-ASK-USGS

Any use of trade, product, or firm names is for descriptive purposes only and does not imply endorsement by the U.S. Government.

Although this report is in the public domain, permission must be secured from the individual copyright owners to reproduce any copyrighted materials contained within this report.

On the cover:

Valzinco mine site prior to reclamation in February 2001. Photograph by Jane M. Hammarstrom.

Suggested citation:

Hammarstrom, J.M., Johnson, A.N., Seal, R.R., II, Meier, A.L., Briggs, P.L., and Piatak, N.M., 2006, Geochemical and mineralogical characterization of the abandoned Valzinco (lead-zinc) and Mitchell (gold) mine sites prior to reclamation: U.S. Geological Survey Scientific Investigations Report 2006—5085, 27 p. 


\section{Preface}

The environmental impacts of mining massive sulfide deposits and gold deposits are distinctly different. Abandoned mines representing both types of deposit are present in the eastern United States. In some cases, both deposit types were mined within a single watershed. Massive sulfide deposits are characterized by high concentrations of heavy-metal sulfide minerals, generally hosted by silicate rocks. Thus, weathering of these deposits and their mine wastes has the potential to generate heavy-metal-laden sulfuric acid that can have negative effects on aquatic ecosystems. The heavy metals that are encountered in these deposits and that are most likely to cause environmental impacts include copper, zinc, lead, cadmium, and arsenic. In addition, the weathering of pyrite releases large amounts of iron, and the acid generated attacks the country rocks. Acid dissolution of rock-forming silicate minerals in the country rock releases aluminum, which also can severely impact aquatic ecosystems. Low-sulfide quartz-gold deposits typically are characterized by low acid-generating potential and low endowments of heavy metals, except for arsenic in some deposits. The greatest potential source of adverse environmental impacts is mercury, which historically was imported to the site and used to extract gold from the ores by a process known as mercury amalgamation.

The central Virginia gold-pyrite belt is an example of a mineral belt that contains both types of deposits. This study addresses the geoenvironmental signature of mine wastes from the Valzinco lead-zinc mine and the Mitchell gold prospect, two abandoned sites situated along

Knights Branch in Spotsylvania County, Va. Both mines were prioritized for reclamation under the Virginia Orphaned Land Program because of acid-mine drainage and mercury concerns. 


\section{Acknowledgments}

This study was conducted in cooperation with the Virginia Department of Mines, Minerals, and Energy (VDMME). The U.S. Geological Survey Mineral Resources Program and the VDMME Orphaned Mine Lands Program provided funding for this research. The cooperation and support of Allen Bishop and Robert Sobeck (VDMME) are greatly appreciated. Meralis Plaza Toledo, Tim Muzik, John Jackson, Andrew Ouimette, and John Wormington assisted in the fieldwork. Eleanora Robbins identified organisms in stream flocs. The manuscript benefited from reviews by Robert Ayuso and Rob Robinson. 


\section{Contents}

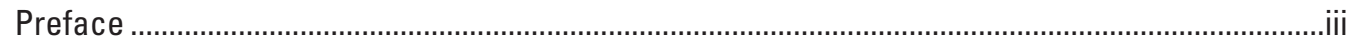

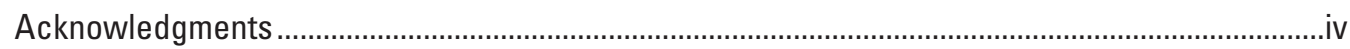

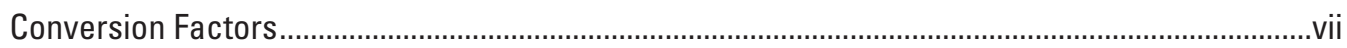

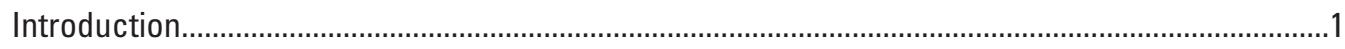

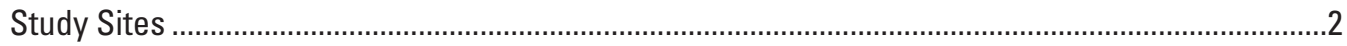

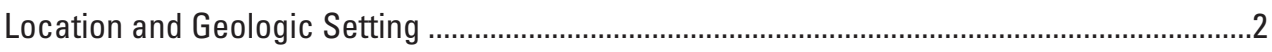

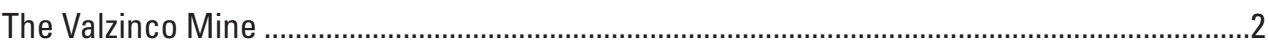

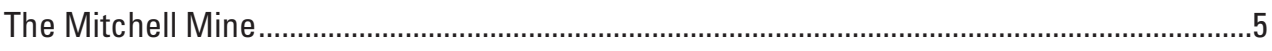

Fluvial Tailings Deposits along Knights Branch.................................................................6

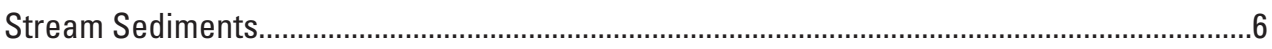

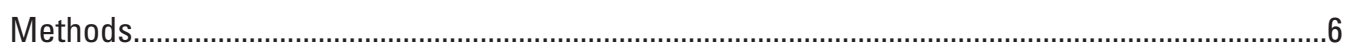

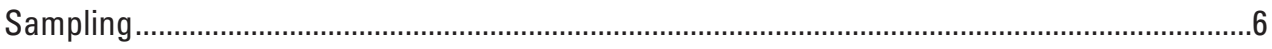

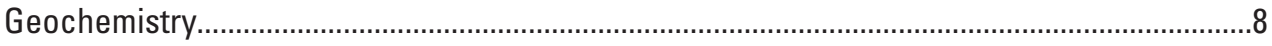

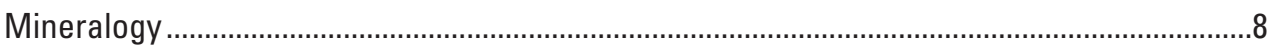

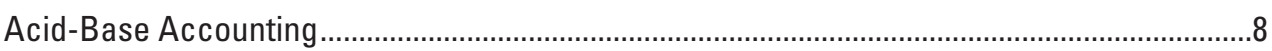

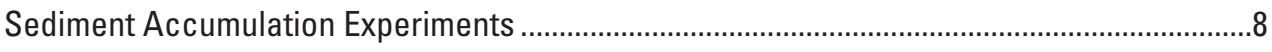

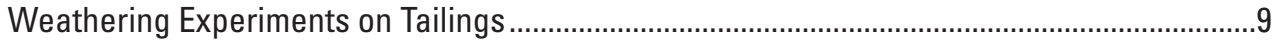

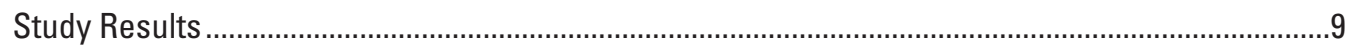

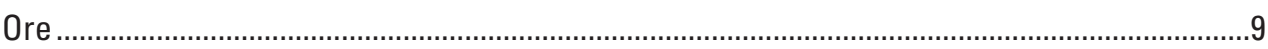

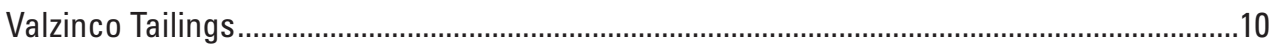

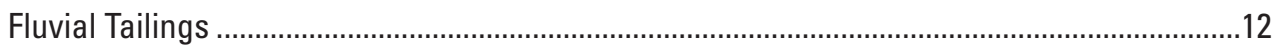

Comparison of Valzinco Mine Tailings with Downstream Fluvial Tailings........................14

Mitchell Mine Pond Sediments ..............................................................................................17

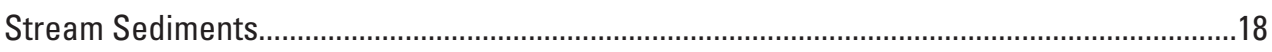

Sediment Accumulation Experiments .........................................................................19

Weathering Experiments on Tailings .....................................................................................22

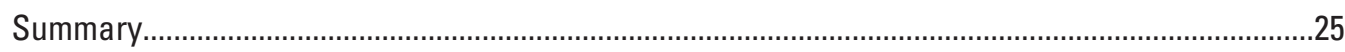

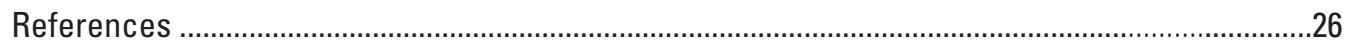

Appendix..................................................................................................... [click here to open file]

\section{Figures}

1. Lithologic map of the southwestern part of the Fredericksburg $30^{\prime} \times 60$ 'quadrangle.........1

2. Topographic map of the southeastern part of the Belmont $1: 24,000$ quadrangle ..............3

3. Sample locations for Valzinco flotation tailings, downstream fluvial tailings deposits, stream sediments, pond sediments at the Mitchell mine, and a background soil

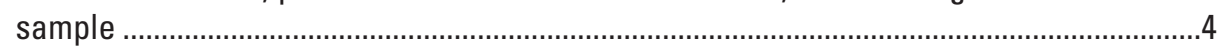

4. Photographs of the Valzinco mine area ................................................................................

5. Photographs of the Mitchell mine area ................................................................................

6. Photographs of fluvial tailings deposits downstream of Valzinco tailings dam

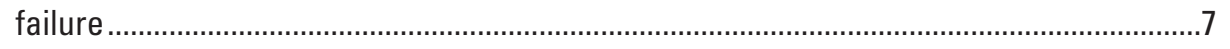

7. Site photographs of sediment accumulation experiment along Knights Branch ..............9 
8. Valzinco mine tailings.

9. Schematic cross-section of fluvial tailings deposit 3 ...

10. Bar chart comparing total base-metal concentrations in Valzinco mine tailings, downstream fluvial deposits, and background soil ...........................................................17

11. Stream sediment geochemistry along Knights Branch..................................................21

12. Sediment accumulation experiment.................................................................................22

13. Bar charts showing the relative increase in base-metal concentrations in sediment and concomitant decreases in dissolved base-metal concentrations in stream water between February 7 and April 30, 2001 ................................................................24

14. Photograph of the weathering experiment on Valzinco unoxidized tailings ....................25

\section{Tables}

1A. Geochemistry of Valzinco ore ........................................................................................ 10

1B. Mineral chemistry by electron microprobe........................................................................10

2. Mineralogy of flotation tailings from Valzinco mine spoil pile 1........................................10

3. Selected geochemical data for Valzinco mine tailings ....................................................12

4. Acid-base accounting data for Valzinco tailings.........................................................13

5. Selected geochemical data for Valzinco fluvial tailings ....................................................15

6. Selected geochemical data for Mitchell mine pond sediments ......................................18

7. Selected geochemical data for Knights Branch and background stream

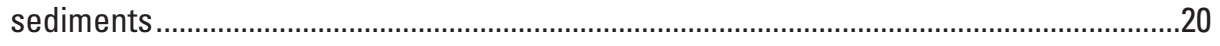

8. Selected geochemical data for Knights Branch accumulated sediments ......................23 


\section{Conversion Factors}

Inch/Pound to SI

\begin{tabular}{|c|c|c|}
\hline Multiply & By & To obtain \\
\hline \multicolumn{3}{|c|}{ Length } \\
\hline inch (in.) & 2.54 & centimeter $(\mathrm{cm})$ \\
\hline inch (in.) & 25.4 & millimeter $(\mathrm{mm})$ \\
\hline foot $(\mathrm{ft})$ & 0.3048 & meter $(\mathrm{m})$ \\
\hline mile (mi) & 1.609 & kilometer (km) \\
\hline mile, nautical (nmi) & 1.852 & kilometer (km) \\
\hline yard (yd) & 0.9144 & meter $(\mathrm{m})$ \\
\hline \multicolumn{3}{|c|}{ Area } \\
\hline acre & 4,047 & square meter $\left(\mathrm{m}^{2}\right)$ \\
\hline acre & 0.4047 & hectare (ha) \\
\hline acre & 0.4047 & square hectometer $\left(\mathrm{hm}^{2}\right)$ \\
\hline acre & 0.004047 & square kilometer $\left(\mathrm{km}^{2}\right)$ \\
\hline square mile $\left(\mathrm{mi}^{2}\right)$ & 259.0 & hectare (ha) \\
\hline square mile $\left(\mathrm{mi}^{2}\right)$ & 2.590 & square kilometer $\left(\mathrm{km}^{2}\right)$ \\
\hline \multicolumn{3}{|c|}{ Mass } \\
\hline pound, avoirdupois (lb) & 0.4536 & kilogram $(\mathrm{kg})$ \\
\hline ton, short $(2,000 \mathrm{lb})$ & 0.9072 & megagram (Mg) \\
\hline ton, long $(2,240 \mathrm{lb})$ & 1.016 & megagram $(\mathrm{Mg})$ \\
\hline \multicolumn{3}{|l|}{ SI to Inch/Pound } \\
\hline Multiply & By & To obtain \\
\hline \multicolumn{3}{|c|}{ Length } \\
\hline centimeter $(\mathrm{cm})$ & 0.3937 & inch (in.) \\
\hline millimeter $(\mathrm{mm})$ & 0.03937 & inch (in.) \\
\hline meter $(\mathrm{m})$ & 3.281 & foot $(\mathrm{ft})$ \\
\hline kilometer $(\mathrm{km})$ & 0.6214 & mile (mi) \\
\hline kilometer $(\mathrm{km})$ & 0.5400 & mile, nautical (nmi) \\
\hline meter $(\mathrm{m})$ & 1.094 & yard $(\mathrm{yd})$ \\
\hline \multicolumn{3}{|c|}{ Area } \\
\hline square meter $\left(\mathrm{m}^{2}\right)$ & 0.0002471 & acre \\
\hline hectare (ha) & 2.471 & acre \\
\hline square hectometer $\left(\mathrm{hm}^{2}\right)$ & 2.471 & acre \\
\hline square kilometer $\left(\mathrm{km}^{2}\right)$ & 247.1 & acre \\
\hline
\end{tabular}

Temperature in degrees Celsius $\left({ }^{\circ} \mathrm{C}\right)$ may be converted to degrees Fahrenheit $\left({ }^{\circ} \mathrm{F}\right)$ as follows: ${ }^{\circ} \mathrm{F}=\left(1.8 \times{ }^{\circ} \mathrm{C}\right)+32$

Temperature in degrees Fahrenheit $\left({ }^{\circ} \mathrm{F}\right)$ may be converted to degrees Celsius $\left({ }^{\circ} \mathrm{C}\right)$ as follows: ${ }^{\circ} \mathrm{C}=\left({ }^{\circ} \mathrm{F}-32\right) / 1.8$

Vertical coordinate information is referenced to the insert datum name (and abbreviation) here, for instance, "North American Vertical Datum of 1988 (NAVD 88)"

Horizontal coordinate information is referenced to the insert datum name (and abbreviation) here, for instance, "North American Datum of 1983 (NAD 83)"

Altitude, as used in this report, refers to distance above the vertical datum. 


\title{
Geochemical and Mineralogical Characterization of the Abandoned Valzinco (Lead-Zinc) and Mitchell (Gold) Mine Sites Prior to Reclamation, Spotsylvania County, Virginia
}

\author{
By Jane M. Hammarstrom, Adam N. Johnson, Robert R. Seal II, Allen L. Meier, Paul L. Briggs, and Nadine M. \\ Piatak
}

\section{Introduction}

The Virginia gold-pyrite belt, part of the central Virginia volcanic-plutonic belt, hosts numerous abandoned metal mines (Pavlides and others, 1982). The belt extends from about 50 $\mathrm{km}$ south of Washington, D.C., for approximately $175 \mathrm{~km}$ to the southwest into central Virginia. The rocks that comprise the belt include metamorphosed volcanic and clastic (noncarbonate) sedimentary rocks that were originally deposited during the Ordovician (Horton and others, 1998). Deposits that were mined can be classified into three broad categories: (1) volcanic-associated massive sulfide deposits, (2) low-sulfide quartz-gold vein deposits, and (3) gold placer deposits, which result from weathering of the vein deposits. The massive sulfide deposits were historically mined for iron and pyrite (sulfur), zinc, lead, and copper but also yielded byproduct gold and silver. The most intensely mineralized and mined section of the belt is southwest of Fredericksburg, in the Mineral district of Louisa and Spotsylvania counties (fig. 1). The Valzinco lead-zinc mine and the Mitchell gold prospect are abandoned sites in Spotsylvania County. As a result of environmental impacts associated with historic mining, both sites were prioritized for reclamation under the Virginia Orphaned Land Program administered by the Virginia Department of Mines, Minerals, and Energy (VDMME). The U.S. Geological Survey (USGS) conducted studies of the geochemistry of drainage at the mine sites and along Knights Branch, the stream that flows past both deposits. Seal and others (2002) provided a pre-reclamation assessment of seasonal variations of acid and metal concentrations in Knights Branch to serve as a baseline for judging the success of reclamation at Valzinco. Water quality in Knights Branch was impaired from Valzinco to some point downstream of the Mitchell mine (Sobeck, 2000; Seal and others, 2002) according to water quality standards for aquatic ecosystems established by the U.S. Environmental Protection Agency (EPA) (EPA, 1996). The VDMME began reclamation of the Valzinco mine site in April 2001 and completed the project in April 2002. Evaluation of reclamation options for

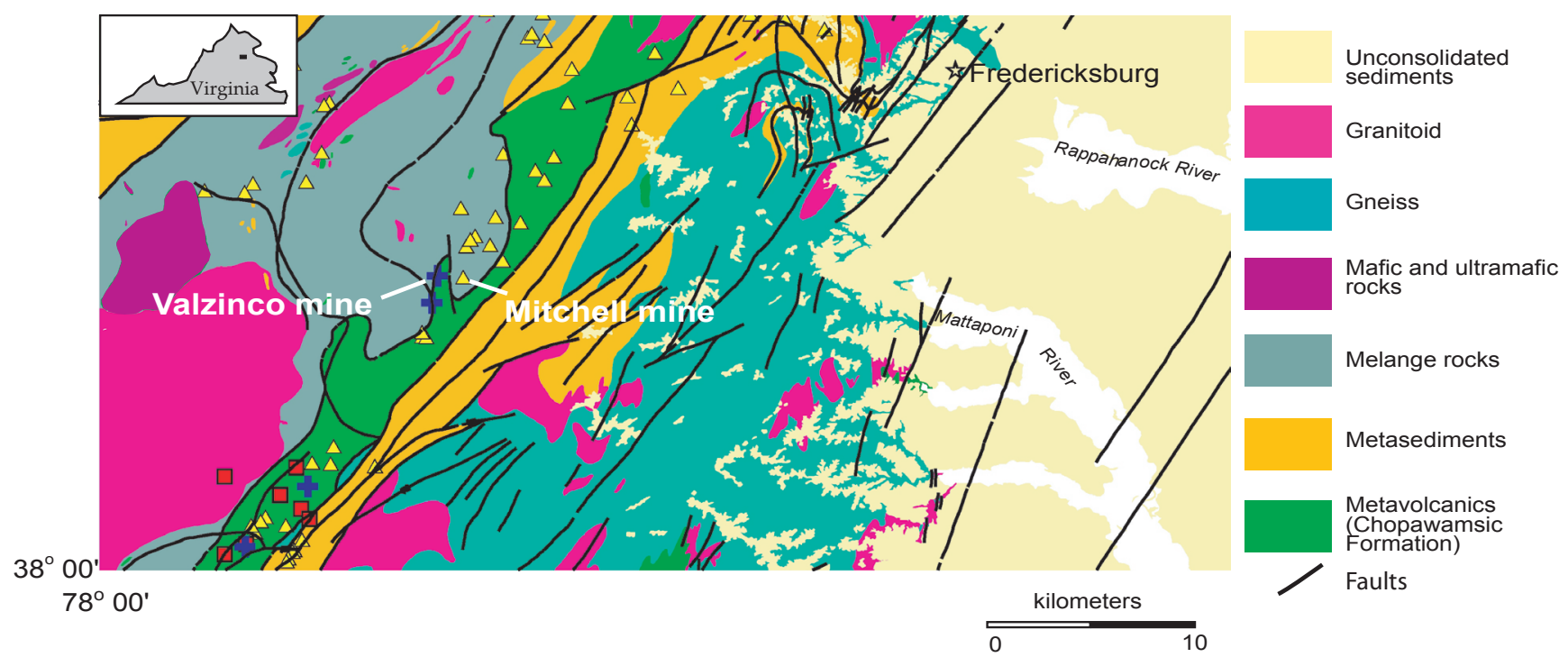

Figure 1. Lithologic map of the southwestern part of the Fredericksburg 30'x60'quadrangle showing the distribution of gold (yellow triangles), lead-zinc (blue crosses), and pyrite (red squares) mines and prospects. Lithologic base simplified from Davis and others (2001). 
the Mitchell mine site and post-reclamation assessment of the Valzinco reclamation were underway in 2004.

In addition to water, a variety of solid materials was sampled at the Valzinco and Mitchell mines between 1999 and 2003. Solid sample media included flotation tailings, ore, stream sediments, pond sediments, streambed precipitates, and secondary minerals. Johnson and others (2000) presented preliminary data on the mineralogy and geochemistry of sulfidic mine waste at Valzinco and discussed implications for acid-generating and acid-neutralizing potential. Hammarstrom and others (2005) described the efflorescent sulfate minerals at the Valzinco mine.

This report summarizes geochemical data for all solid sample media, along with mineralogical data, and results of weathering experiments on Valzinco tailings and field experiments on sediment accumulation in Knights Branch. These data provide a framework for evaluating water-rock interactions and geoenvironmental signatures of long-abandoned mines developed in massive sulfide deposits and low-sulfide gold-quartz vein deposits in the humid temperate ecosystem domain in the eastern United States.

\section{Study Sites}

\section{Location and Geologic Setting}

The Valzinco and Mitchell mines are located along Knights Branch of Northeast Creek in the Belmont 7.5' quadrangle in southern Spotsylvania County (fig. 2). Northeast Creek flows into the North Anna River below Lake Anna Dam. The Anna River discharges into the Chesapeake Bay. The mineral deposits that host the mines occur in crystalline metamorphic rock of the Piedmont Province. An early geologic map of the pyrite-gold belt in Louisa and Spotsylvania Counties located both mines within Precambrian and undifferentiated Cambrian micaceous schist (Cline and others, 1921). The modern geologic map of the Fredericksburg 30'x60' quadrangle (Mixon and others, 2000; Davis and others, 2001) shows that the Valzinco mine, like the other kuroko-type massive sulfide deposits in the gold-pyrite belt, is hosted by metamorphosed volcanic rocks of the Cambrian Chopawamsic Formation (fig. 1) of the central Virginia volcanic-plutonic belt of Pavlides (1989). These rocks are interpreted as the continentward side of an allocthonous island-arc tectonostratigraphic terrane (Pavlides, 1989). On the Fredericksburg geologic map, the Mitchell mine site lies within a fault-bounded melange unit of the Ordovician and(or) Cambrian Mine Run Complex (fig. 1). The rocks are fine-grained schists and phyllites that include exotic blocks of metavolcanic rocks similar to the Chopawamsic Formation. The Mine Run Complex is interpreted as a back-arc basin terrane (Mixon and others, 2000). The Mitchell mine is one of many gold-quartz vein deposits that cross a variety of rock types, including the Chopawamsic Formation.
The gold belt converges on the Chopawamsic contact near the Valzinco mine. On the basis of angular discordance and crosscutting relations, the gold deposits are considered to be younger than both the volcanic rocks and the massive sulfide deposits (Pavlides and others, 1982). Most of the productive veins of the gold belt were less than $2 \mathrm{~m}$ thick, on the order of $100 \mathrm{~m}$ long, and mined by surface workings.

\section{The Valzinco Mine}

The abandoned Valzinco mine ( $38^{\circ} 10.68^{\prime}$ N., $77^{\circ} 47.90^{\prime}$ W.), also known as the Halladay, Holladay, or Holloday mine, is located at the headwaters of Knights Branch, approximately 2.2 km south-southwest of Porters (fig. 2). The host rock quartzsericite schists in the mine area are metamorphosed to upper greenschist to lower amphibolite grade (Pavlides and others, 1982). The deposits occur as two subparallel massive sulfide lenses ("veins") that strike approximately N40E and dip at an angle of 60 to $70^{\circ} \mathrm{SE}$, crossing the foliation in the country rock. The Holloday "vein" and the Discovery "vein" were found during exploration drilling in the 1940s. The Holloday orebody, the larger of the two, was mined to a depth of approximately 115 $\mathrm{m}$ along a strike length of approximately $180 \mathrm{~m}$. Vein thickness varied from 0.6 to $3.0 \mathrm{~m}$, with an average thickness of $1.2 \mathrm{~m}$. The Discovery orebody was mined to a depth of approximately $75 \mathrm{~m}$ to within $15 \mathrm{~m}$ of the surface, with a strike length of $95 \mathrm{~m}$ (Poole, 1974). Ore consisted of massive accumulations of pyrite $\left(\mathrm{FeS}_{2}\right)$, sphalerite $(\mathrm{ZnS})$, galena $(\mathrm{PbS})$, and minor chalcopyrite $\left(\mathrm{CuFeS}_{2}\right)$ and pyrrhotite $\left(\mathrm{Fe}_{1-\mathrm{x}} \mathrm{S}\right)$. Gangue included quartz, chlorite, and magnetite. In the immediate vicinity of the orebodies, the wallrocks are silicified, pyritized, and chloritized (Poole, 1974). The geologic and geochemical features of the deposit conform to the "Kuroko-type" classification of seafloor massive sulfide deposits, which is characterized by massive accumulations of pyrite and subordinate amounts of chalcopyrite, sphalerite, and galena; host rocks are typified by a felsic-dominated suite of bimodal volcanic rocks with associated siliciclastic sedimentary rocks (Seal and others, 2000).

The Valzinco deposit produced lead and zinc. The Virginia Lead and Zinc Company opened the mine in 1914. Initially, the ores were hauled to a mill at the Allah-Cooper mine approximately $29 \mathrm{~km}$ to the southwest. Between 1914 and 1918, the mine produced about 5,000 short tons (4,500 metric tonnes) of ore averaging 5 percent lead and 12.5 percent zinc (Grosh, 1949). The mine changed hands in the 1920s; although some development work occurred, no production records exist. In 1942, Panaminus, Inc., reopened the mine with on-site processing facilities consisting of a modern mill capable of handling 100 tons of ore per day and a flotation plant. At the same time, Panaminus dewatered the 360-ft level of the mine (Poole, 1974). The mine was worked from a 75-m vertical main shaft to a depth of $105 \mathrm{~m}$ below the shaft. The U.S. Bureau of Mines documented the extent of underground workings and the mining methods used when they drilled the deposit in 1943 to outline the orebody and increase reserves 


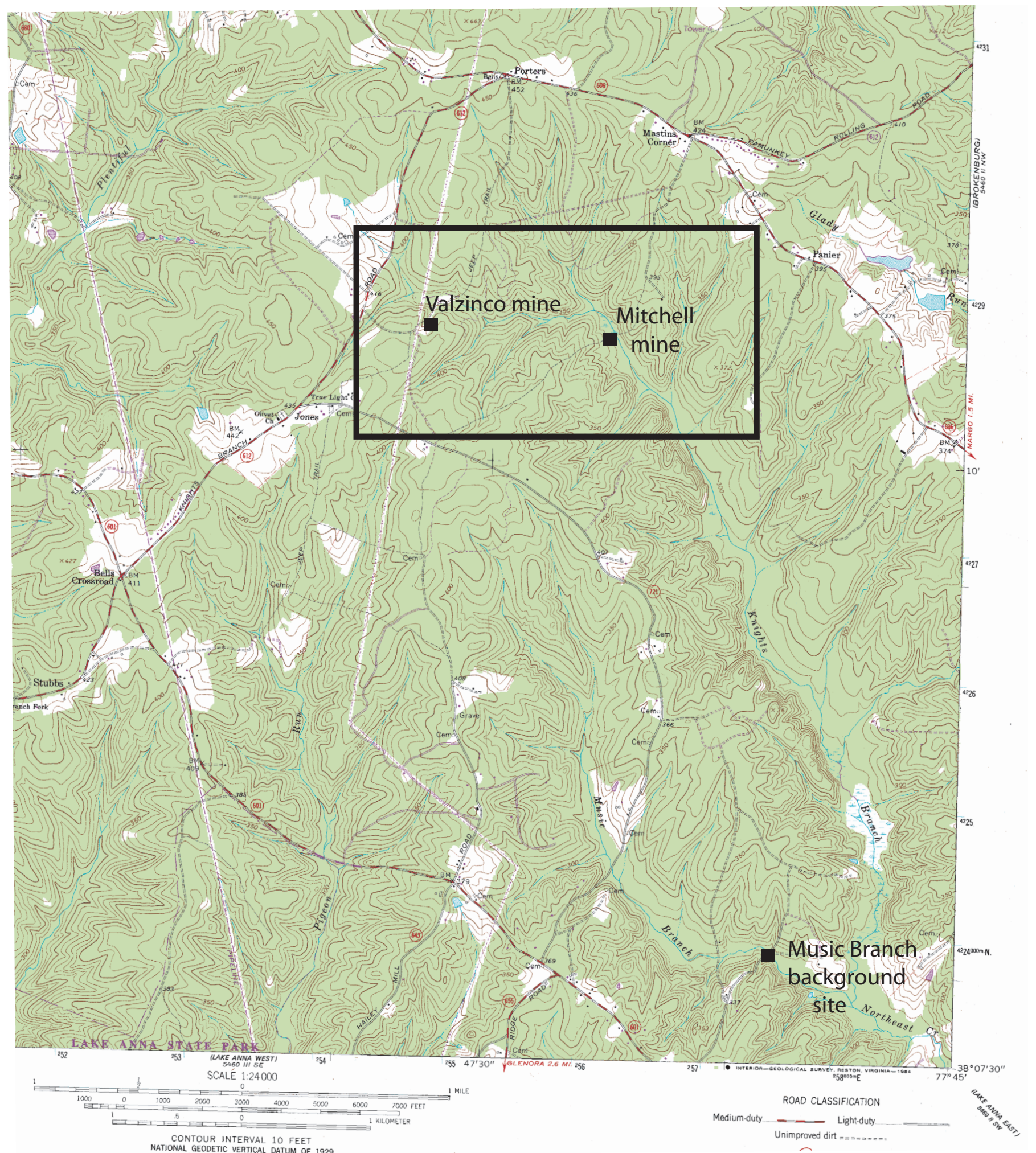

Figure 2. Topographic map of the southeastern part of the Belmont 1:24,000 quadrangle showing the location of the Valzinco mine, the Mitchell mine, and the Music Branch background site. Rectangle shows location of figure 3. 
(Grosh, 1949). Initially, the deposit was mined by shrinkage stoping, but problems with bad ground necessitated a change to stulled stoping. Underground workings included five mine levels and more than 1,500 $\mathrm{m}$ of workings. The ore processed in the flotation plant averaged 7.5 percent zinc, 3.5 percent lead, and 1 percent copper. Products included a lead-zinc concentrate and a zinc concentrate. Fine-grained tailings from the 1940s mining operations deposited in and along Knights Branch resulted in a disturbed area of about $40,000 \mathrm{~m}^{3}$.

Before site reclamation, the Valzinco mine site consisted of underground mine workings and extensive spoil piles composed of fine-grained flotation mill tailings deposited within and adjacent to the stream channel (fig. 3). Knights Branch flowed from its headwaters above the mine site through a pile of flotation tailings (fig. $4 A$ ). Erosion along the stream bank and erosion gullies on tailings surfaces exposed unoxidized tailings and formed puddles and channels of extremely acidic water $(\mathrm{pH}<2)$. The pre-reclamation location of the road through the site and a bridge over Knights Branch represented the remnants of a dam structure built across the stream channel and floodplain that served as a tailings pond. Dam failure (date unknown) caused fluvial transport of tailings downstream from the site. The mill foundation and a concrete silo remained on the site after mining ceased, at the head of a tailings-lined gulch (fig. $4 C$ ) that formerly served as the discharge pond area for flotation mill slimes. The gulch below the mill was probably a pond area at one time but was dry (except for surface runoff) during the course of this study. The gulch walls were composed of very-fine grained oxidized tailings. A variety of highly soluble sulfate minerals effloresced on the tailings intermittently during the course of this study, depending on the prevailing weather conditions (fig. 4D).

In the late 1990s, the VDMME evaluated reclamation strategies to address acid-drainage problems in Knights Branch under the Commonwealth's Orphaned Lands Program established in 1978 under Virginia Mineral Mining Reclamation Law. The project was designed to address acid-mine drainage and heavy metal loadings in the Lower North Anna River/Northeast Creek watershed (Allen Bishop, written communication, 1999). Tailings in and adjacent to Knights Branch and acid seeps from underground workings had impacted the stream. Site characterization (water quality and acid base

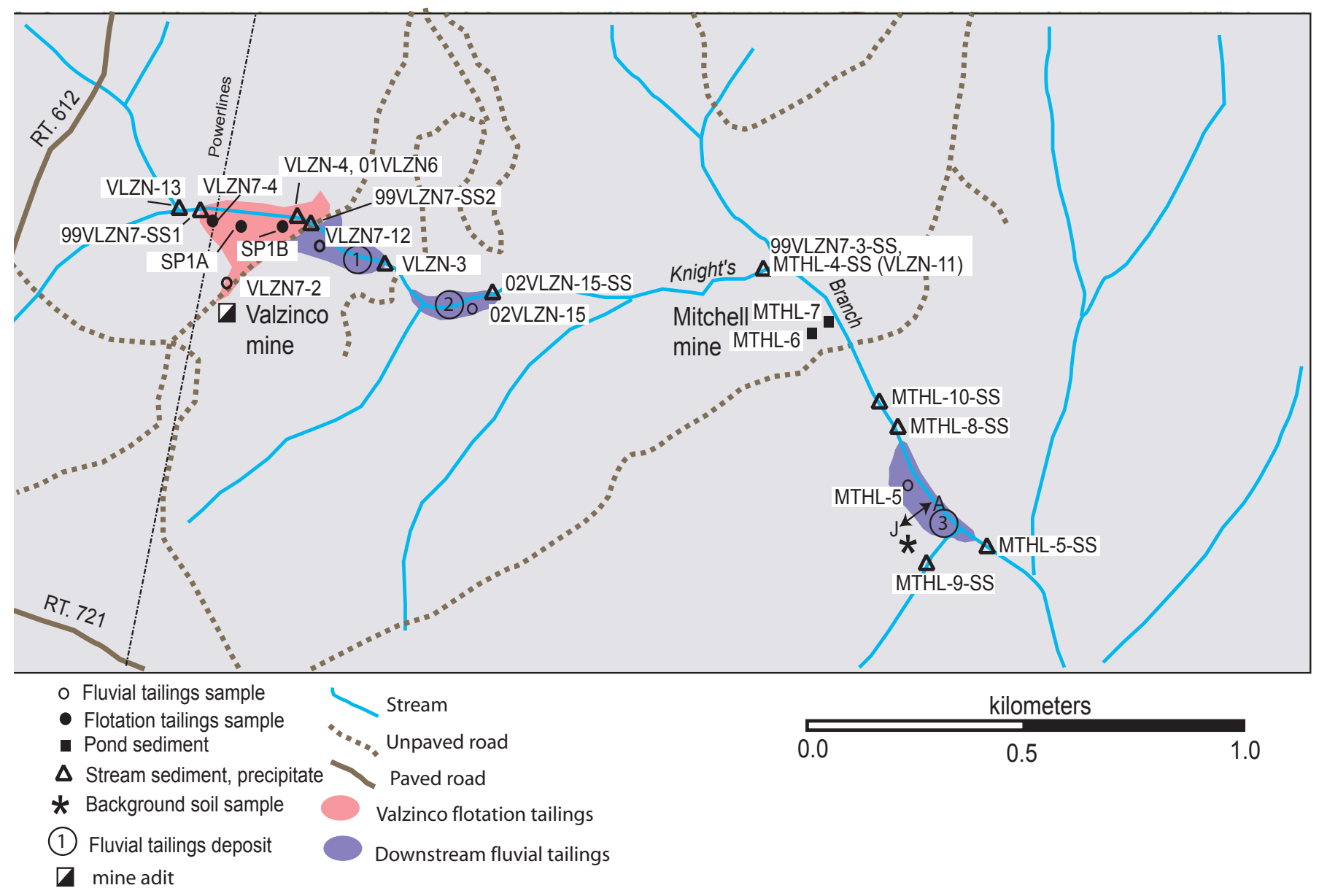

Figure 3. Sample locations for Valzinco flotation tailings (solid circles), downstream fluvial tailings deposits (open circles), stream sediments (SS samples shown as open triangles), pond sediments at the Mitchell mine (solid squares), and a background soil sample (asterisk). Fluvial tailings deposit 1 is at the downstream end of Valzinco mine site; deposit 2 is $\sim 0.25 \mathrm{~km}$ downstream of the Valzinco mine site; deposit 3 is downstream of the Mitchell mine. Fluvial tailings deposit 3 was augered to a depth of $93 \mathrm{~cm}$ at locations A through $\mathrm{J}$. 
accounting to determine treatment dosages for acid abatement) was conducted by MVTechnologies, Inc. (1998) under contract with the VDMME. That study and grab water samples analyzed by the Commonwealth showed acidic soils (paste $\mathrm{pH}$ 3.2) and elevated concentrations of iron, lead, manganese, and zinc in Knights Branch as it flowed through the Valzinco mine site. The project goals included restoration of Knights Branch and reclamation and revegetation of more than 4.0 hectares $(10$ acres) of disturbed lands. Reclamation included (1) the landfilling of mine wastes, (2) the construction of water diversion channels, (3) the construction of anoxic limestone drainages, (4) the application of bacteriocides, (5) the construction of wetlands, (6) revegetation, and (7) plugging of shafts (Sobeck, 2000). The dry gulch area below the flotation mill site was used as a repository for tailings. Water diversion and recontouring have resulted in a wetland/pond system that occupies the former stream channel through the tailings (fig. 4B).

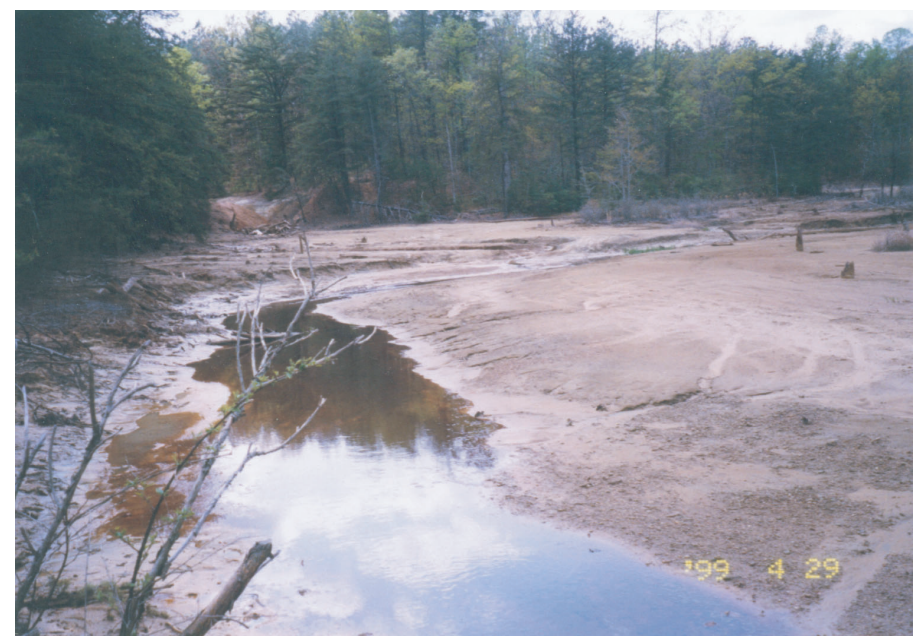

A

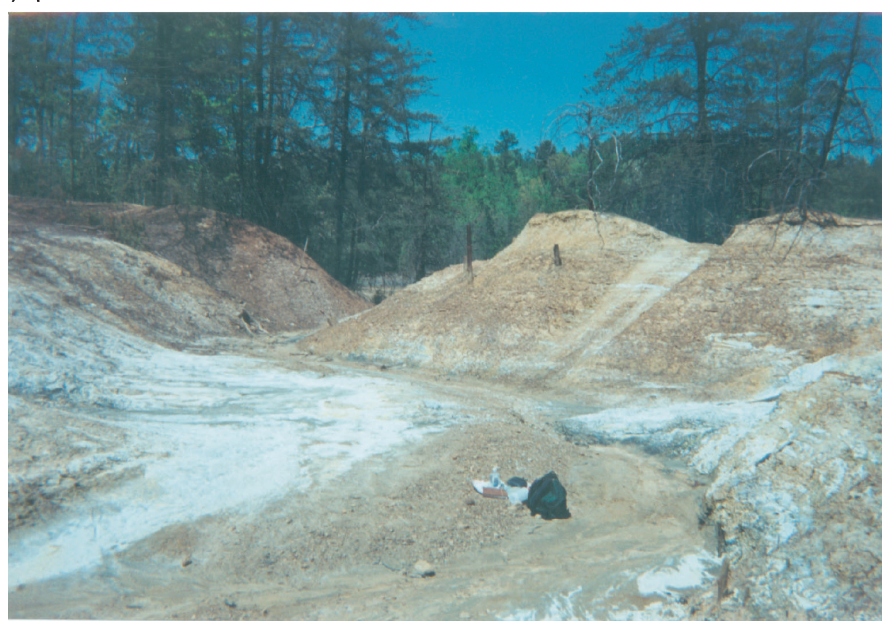

C

\section{The Mitchell Mine}

The Mitchell mine (38 $18^{\prime} 31^{\prime \prime}$ N., $77^{\circ} 46^{\prime} 54^{\prime \prime} \mathrm{W}$.) is located approximately $1.5 \mathrm{~km}$ downstream of Valzinco, on the west bank of Knights Branch in the Belmont 7.5' quadrangle. The Mitchell mine (Old Dominion prospect, Emily prospect) is an abandoned gold mine; no production records exist. Watson (1907) mentioned the Mitchell mine as one of a number of Spotsylvania County gold mines but located the mine on Pigeon Run. Cline and others (1921) correctly located the Mitchell mine on Knights Branch. A 1974 site inspection by the Virginia Division of Mineral Resources described approximately 12 pits and shafts, some water-filled pits (fig. 5), leafcovered dumps, and several piles of quartz at the site (Sweet, 1980; Sweet and Trimble, 1983). The same site description applied when samples were collected for the present study in 2002. Piles of cobble-size quartz are present near the pits

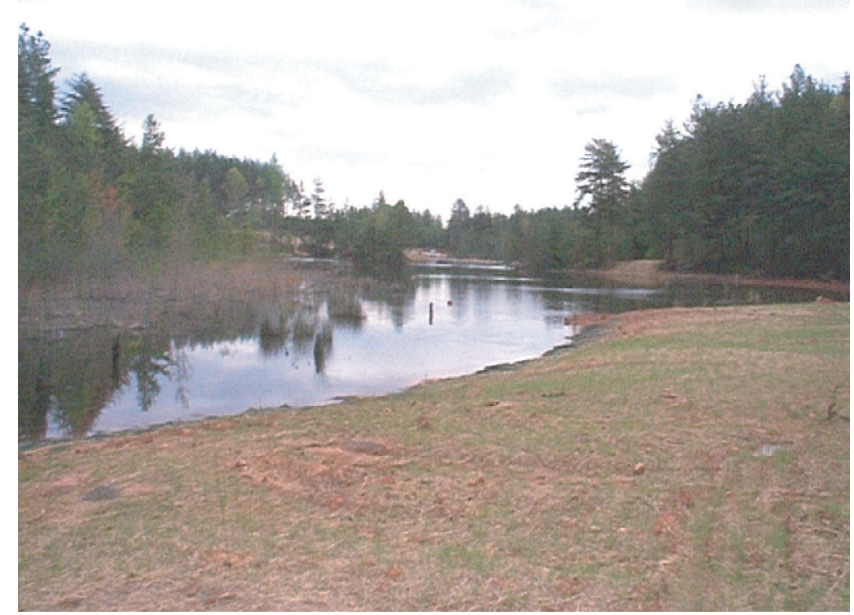

$B$

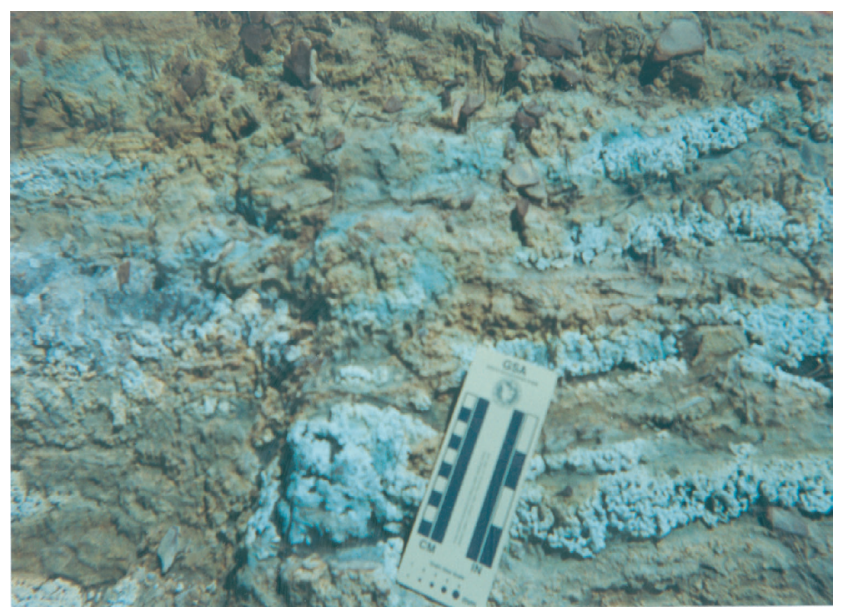

D

Figure 4. Photographs of the Valzinco mine area. $A$, Knights Branch flowing through the Valzinco flotation tailings (April 1999). View west towards headwaters (upper right) and gulch (upper left). $B$, Same area after reclamation (2002). The gulch was filled with tailings and capped. Limestone drains were installed along with rerouting of the main stream channel. $C$, Pre-reclamation view from the flotation plant foundation looking northeast along the tailings-lined gulch. $D$, Efflorescent sulfate salts coating tailings along the gulch. 
and along the creek. The mine area is densely vegetated; the hummocky topography in the mine area is the only indication of the historic mine workings. The area is currently used for timber. The site is on private property and is no longer accessible by road. Pond bottom sediments from two water-filled depressions (fig. 5) were sampled for mercury, which was likely used for amalgamation of gold on site.

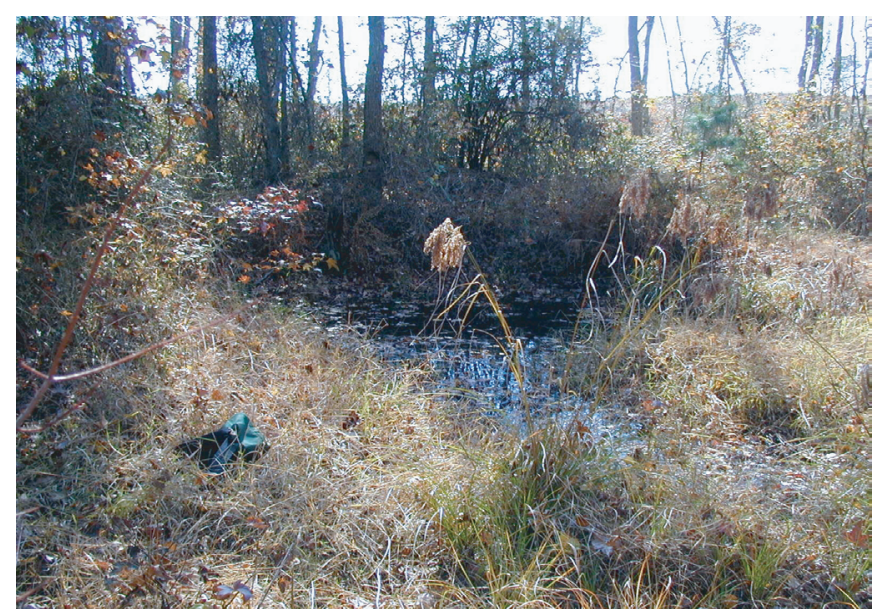

A

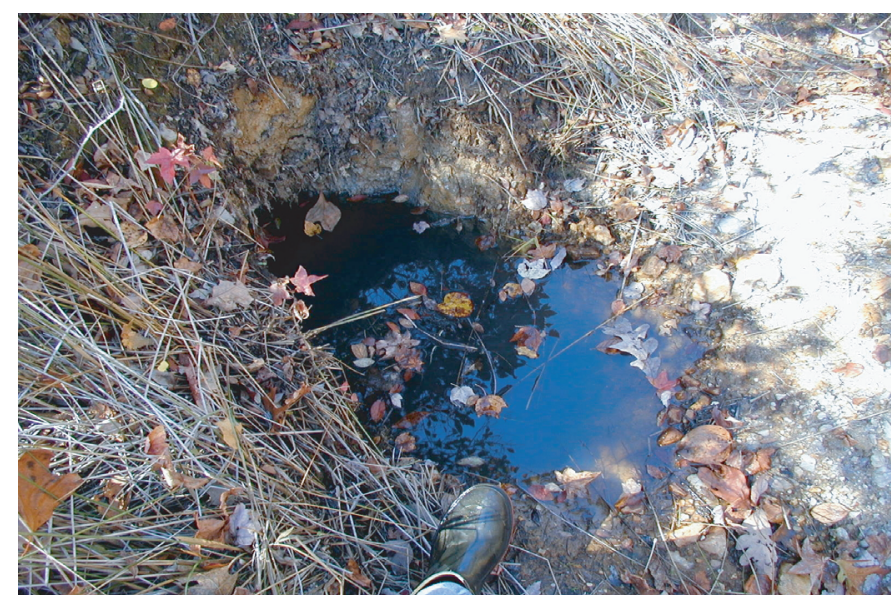

$B$

Figure 5. Photographs of the Mitchell mine area. $A$, Large pond. $B$, Small pond.

\section{Fluvial Tailings Deposits along Knights Branch}

Three areas of tailings along Knights Branch downstream of the Valzinco mine site were deposited by fluvial transport. The area immediately downstream of the road (fig. 3, deposit 1) and another area of tailings about $200 \mathrm{~m}$ downstream of Valzinco (fig. 3 , deposit 2) probably resulted from the dam failure (fig. 6A). In VDMME reports, the mine tailings are referred to as spoil pile 1, and fluvial tailings deposit 1 is referred to as spoil pile 2 . Before reclamation, the area of spoil pile 2 was littered with trash, and the braided stream meandered across a wide area in several small channels that coalesced into a single channel at the edge of a wooded area. Fluvial deposit 2 is a wide, barren area downstream of deposit 1. It consists of sandy, oxidized sediment that overlies black sulfidic tailings encountered to a depth of at least $85 \mathrm{~cm}$ (fig. 6B). Material overlying the tailings incorporates layers of organic debris. A grayish green plastic clay is exposed along the edge of the tailings at the stream (fig. 6C). Approximately $350 \mathrm{~m}$ downstream of the Mitchell mine pits, fine-grained tailings are deposited in a large clearing along Knights Branch (fig. 3, deposit 3 ; fig. $6 D$ ). The fact that the surface is littered with quartz suggests that the area might have been used for processing Mitchell mine ore. However, the oxidized, orange-brown surface soil overlies unoxidized, black sulfidic tailings at depths of about 5 to $25 \mathrm{~cm}$ (4-10 in) below the surface. These tailings resemble the Valzinco mine flotation tailings and may have been deposited by fluvial transport, possibly during a major storm event or when the dam failed at the mine. Alternatively, the tailings may have been intentionally transported to the site. Poole (1974) reported that Valzinco dump material was removed and used for road metal for logging roads in the area; however, no records indicate that tailings were intentionally transported to this location.

\section{Stream Sediments}

Stream sediments were sampled along approximately 2 $\mathrm{km}$ of Knights Branch from the headwaters above the Valzinco mine to a site downstream of the Mitchell mine (fig. 3). Streamsediment sampling sites were co-located with surface-water sampling sites (Seal and others, 2002). Three samples were collected in July of 1999 before reclamation (fig. 3, samples 99VLZN7-SS1, SS2, and SS3). Six sites were sampled in 2002, including a tributary stream unaffected by mine workings (fig. 3, MTHL-9-SS). Red to orange ochre streambed precipitates characteristic of acid-mine drainage were observed and sampled as far as $1 \mathrm{~km}$ downstream from Valzinco. Music Branch (fig. 2) was sampled as a background site about $0.5 \mathrm{~km}$ upstream from the point where Knights Branch and Music Branch join to form Northeast Creek. At this locality, Music Branch flows through a wooded area. The stream is about $1 \mathrm{~m}$ wide and $0.3 \mathrm{~m}$ deep, lacks gravel bars, and has a silty, fetid bottom. Cline and others (1921) show the Marva lead-zinc prospects at the head of Music Branch. No development or production is recorded for the Marva prospects, which was probably a surface expression of the southern end of the Valzinco deposit.

\section{Methods}

\section{Sampling}

Flotation tailings and downstream fluvial tailings deposits were sampled by collecting composite (30 increment) samples 


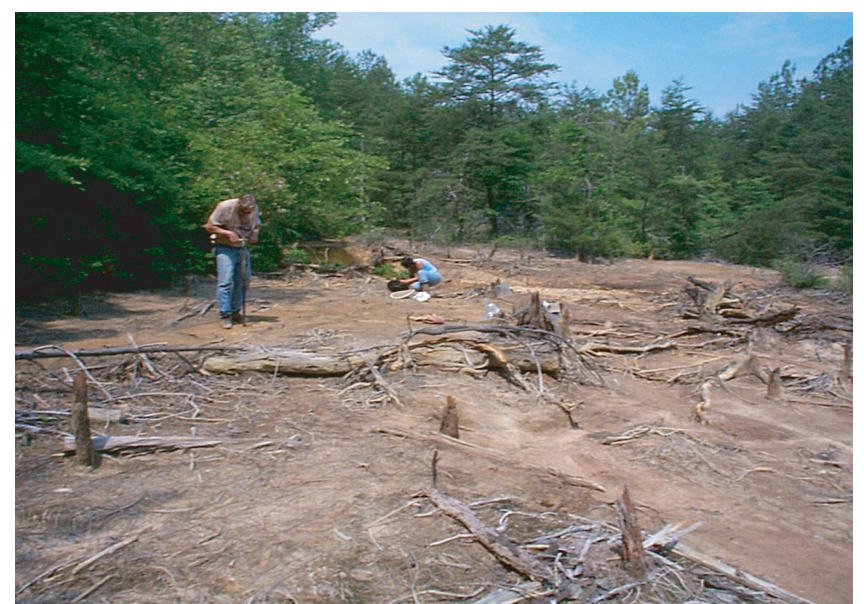

A

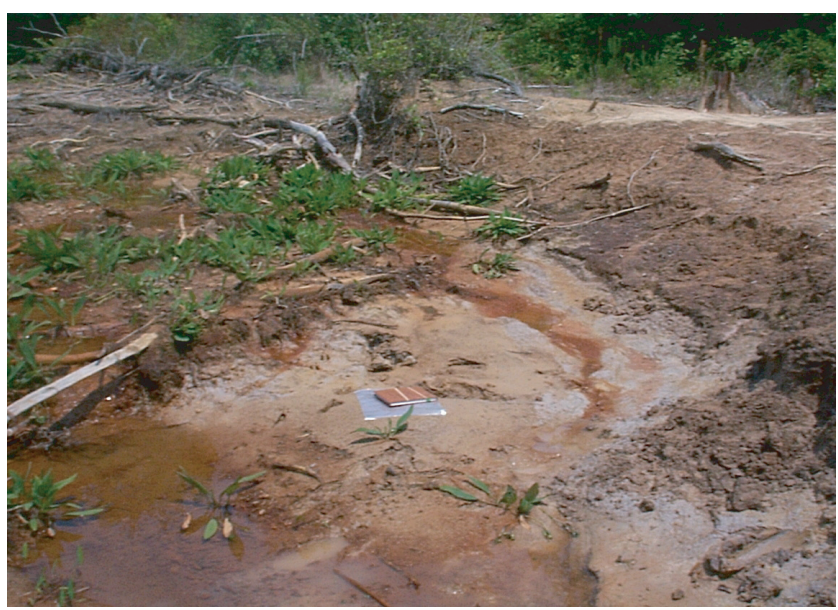

C

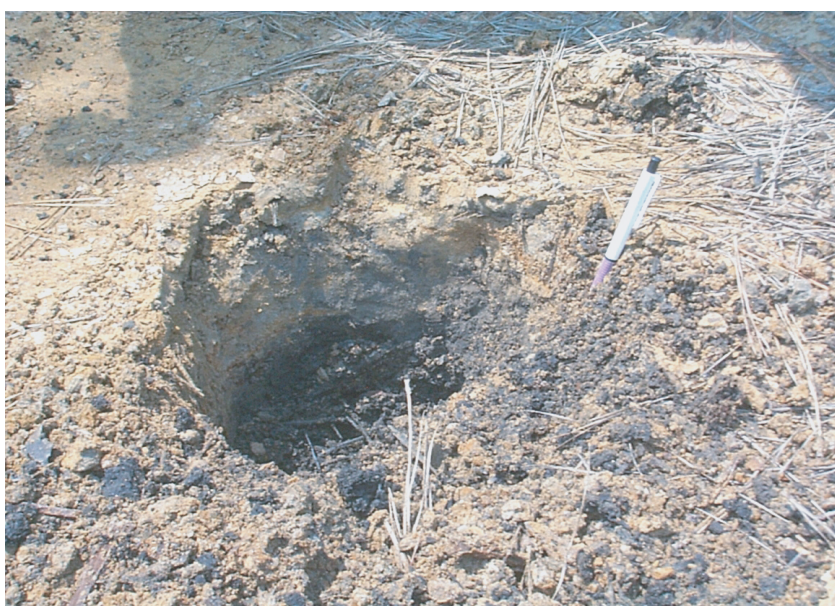

$B$

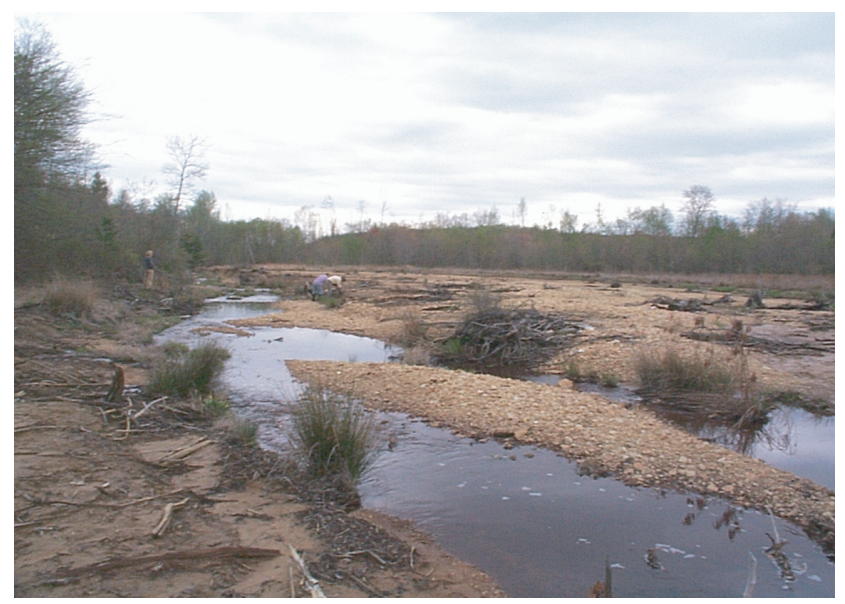

$D$

Figure 6. Photographs of fluvial tailings deposits downstream of Valzinco tailings dam failure. $A$, Sampling surface material on fluvial tailings deposit 2. B, Profile showing sandy sediment over black tailings on fluvial tailings deposit 2. Note pen for scale. $C$, Gray-green clay exposed at fluvial tailings deposit 2. D, Knights Branch at fluvial tailings deposit 3 (quartz-littered flat area on the right).

of the upper $5 \mathrm{~cm}$ of surface material by using a clean, precontaminated stainless steel trowel. Profiles through the tailings piles were sampled by using an auger or by digging holes. Tailings were dry sieved in the field through a $2-\mathrm{mm}$ screen to obtain the nominal soil fraction. Hardpan crusts and efflorescent salts were sampled from tailings surfaces. Precipitates in seeps and along Knights Branch were sampled with a syringe. Stream sediments were sampled by collecting a minimum of 30 subsamples of sediments with a stainless steel trowel. Sediments were wet sieved through a 2-mm screen in the field and placed in plastic bags for transport to the laboratory where they were air dried, weighed, and sieved through an 80-mesh screen. The -80 mesh sediment fraction was submitted for chemical analysis. Pond sediments and the background soil sample (fig. 3) from the Mitchell mine area were sampled in duplicate. Samples for mercury analysis were placed in I-
Chem glass jars to prevent evaporation or atmospheric deposition of mercury prior to analysis.

This report includes data for solid samples that were co-located with water samples at field sites described by Seal and others (2002, in preparation) as well as other samples. Field sites from the Valzinco mine area are identified by the prefix VLZN followed by the site number (VLZN-1,..VLZN13); samples from the Mitchell mine area are designated by the prefix MTHL. For water samples, numbers after the site number designate different sample events. For example, water sample VLZN-3-1 was collected May 22, 1998, whereas water sample VLZN-3-9 was collected April 30, 2001. With the exception of a few stream sediment sites, solids were sampled only once at each site. The appendix contains field site and sample information as well as the complete set of geochemical data for solids. 


\section{Geochemistry}

Ore, tailings, ochres, and stream sediments were analyzed to determine the major-, minor-, and trace-element compositions of the solid material. Sample splits were ground in USGS sample preparation labs in Denver, Colo. (Taggart, 2002). Stream sediments were analyzed for 40 elements by means of inductively coupled plasma-atomic emission spectrometry (ICP-AES). Composite mine-waste surface samples and ochres were analyzed by inductively coupled plasma-mass spectrometry (ICP-MS) and by LECO furnace for total sulfur. A sample of ore was analyzed by these methods and also by wavelength-dispersive X-ray fluorescence spectroscopy (WDXRF). Mercury was analyzed by cold vapor atomic absorption spectrometry (CVAC). Detailed analytical procedures, detections limits, and an evaluation of analytical performance for a variety of geological materials are reported by Briggs (2002) and Briggs and Meier (2002).

National Institute of Standards and Technology certified reference materials were analyzed to monitor accuracy and precision. In addition to replicate field samples, laboratory duplicates on separate aliquots of the same sample were analyzed. USGS job numbers and laboratory number entries are listed in the appendix.

Geochemical data for tailings and stream sediments are compared with reference values, including average soil compositions in the eastern United States (Shacklette and Boerngen, 1984), U.S. Environmental Protection Agency preliminary remediation goals for soils (EPA, 2004), and consensus-based stream sediment quality guidelines for freshwater ecosystems (MacDonald and others, 2000).

\section{Mineralogy}

Mineralogy was characterized by a number of methods, including powder X-ray diffraction (XRD), optical microscopy, scanning electron microscopy (SEM), and mineral separation. For XRD, splits of all samples were pulverized in alcohol in a McCrone micronizer equipped with agate grinding pellets to reduce average particle size to 1 to $5 \mu \mathrm{m}$. Micronized samples were loaded into side-loading aluminum holders. Powder patterns were collected on a Scintag X1 automated diffractometer equipped with a Peltier detector using $\mathrm{CuK} \alpha$ radiation. Patterns were interpreted with the aid of Scintag and MDI Applications JADE search/match software and compared with reference patterns in the Powder Diffraction File (ICDD, 2002). Uncertainties in XRD interpretation were resolved by examining samples under a binocular microscope and by using electron microbeam techniques to confirm the presence and composition of suspected minerals. Epoxy grain mounts were prepared for selected tailings samples. Samples were carbon coated and examined with a JEOL JSM-840 scanning electron microscope (SEM) equipped with a back-scattered electron (BSE) detector, a secondary electron (SE) detector, and a PGT $\mathrm{X}$-ray energy-dispersive system (EDS). EDS spectra were col- lected to obtain qualitative analysis of mineral compositions to refine XRD identifications. The SEM typically was operated at an accelerating voltage of $15 \mathrm{kV}$ and a specimen current of 1 to $2 \mathrm{nA}$. A JEOL electron microprobe was used to analyze sulfide minerals in ore. Heavy-mineral concentrates were obtained by placing a few grams of mine waste into the heavy liquid methylene iodide (specific gravity of 3.3) to separate sulfides and other heavy minerals. The heavy mineral concentrate was extracted from the separatory funnel, washed with acetone, air dried, and examined by XRD and SEM.

\section{Acid-Base Accounting}

Five samples of tailings from the main waste pile at the Valzinco mine were submitted for acid-base accounting (Sobek and others, 1978). Samples included oxidized material in surface composites from the western and eastern ends of the pile as well as black unoxidized tailings from depths of 20, 122 , and $180 \mathrm{~cm}$ within the piles. Samples were submitted to BC Research, Inc., ActLabs, and Chemex Labs. The neutralization potential and total sulfur concentrations were determined by the Sobek procedure and by the modified Sobek procedure that determines neutralization potential (NP) by treating the sample with an excess of $\mathrm{HCl}$ at ambient temperature for 24 hours before titration with a standardized base to an endpoint of $\mathrm{pH}$ 8.3. Jambor (2003) presented a discussion of acid-base accounting methods.

\section{Sediment Accumulation Experiments}

A field experiment was conducted to estimate the rates of accumulation of ochreous precipitates along Knights Branch. Samples of the uppermost streambed sediment along Knights Branch were sampled on February 7, 2001, at four of the longterm water sampling sites. The sample sites were (1) VLZN13 upstream from the mine site, (2) VLZN-4 just upstream of the bridge where Knights Branch flowed through the tailings piles, (3) VLZN-3 downstream of the extent of the Valzinco mine reclamation project, and (4) VLZN-11 approximately 1 $\mathrm{km}$ downstream of the Valzinco mine. Samples were collected by siphoning the topmost layer of streambed sediment into a syringe. The water/sediment mixture was deposited in a $50-\mathrm{mL}$ polypropylene centrifuge tube and allowed to settle. Excess water was decanted, and the process was repeated to obtain sufficient material for chemical analysis. Several different types of substrates were placed in the stream at each of the four sites and left for 2 months to allow precipitates to accumulate on substrate surfaces. Substrates included a wood dowel, a length of PVC pipe, glazed ceramic tile, a $2.5-\mathrm{cm}$ round carbon planchet, and glass microslides. Substrates were attached to a wood stake using monofilament line (fig. 7A-D). Samples were retrieved on April 30, 2001, at which time the water level in the creek was significantly lower at downstream site VLZN-11, where some of the samples were suspended above the water level. Samples were placed in plastic bags for 


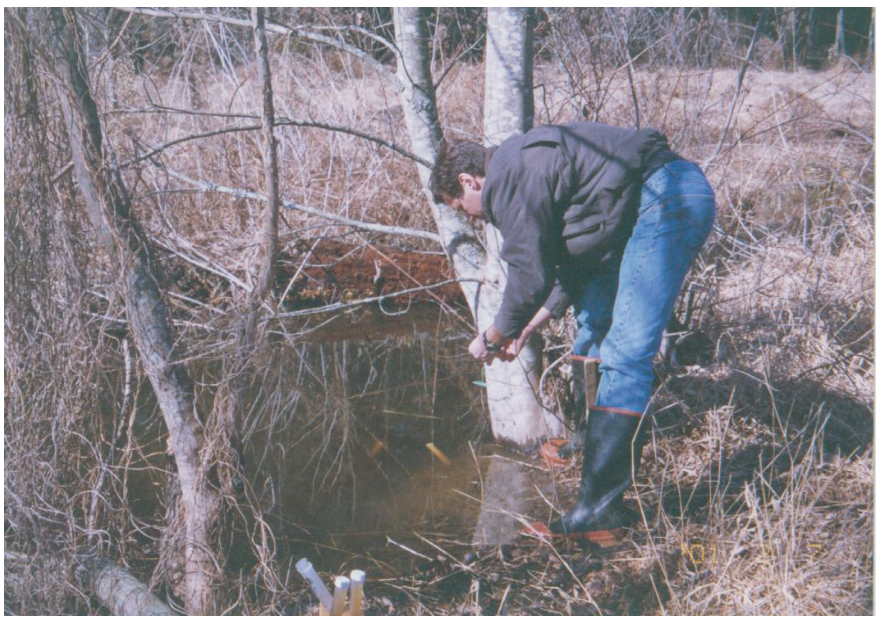

A

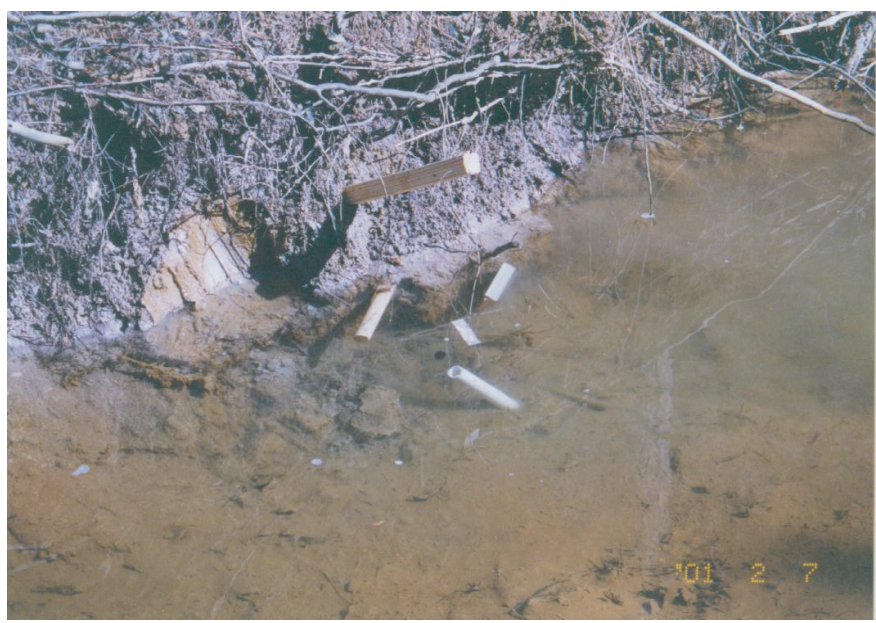

C

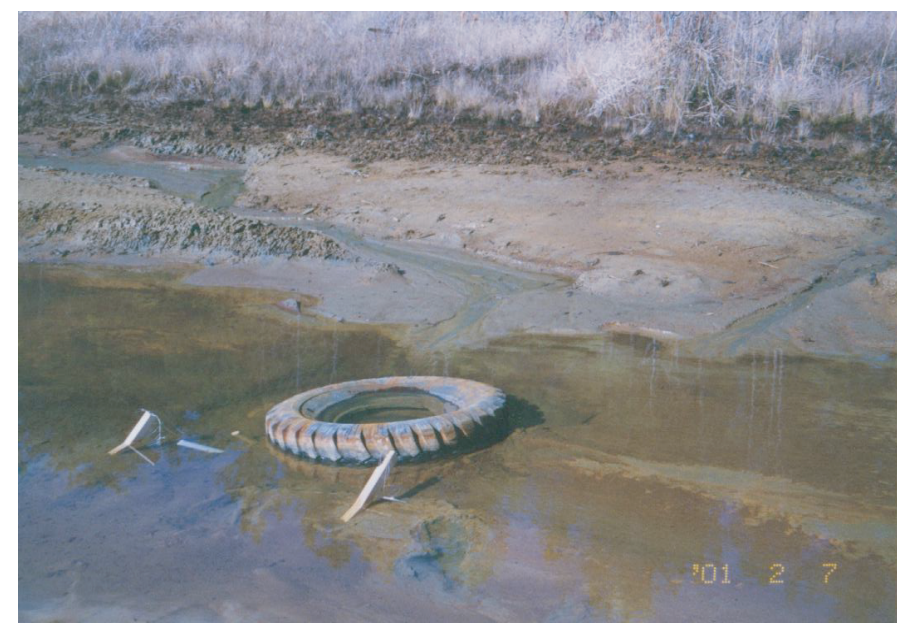

B

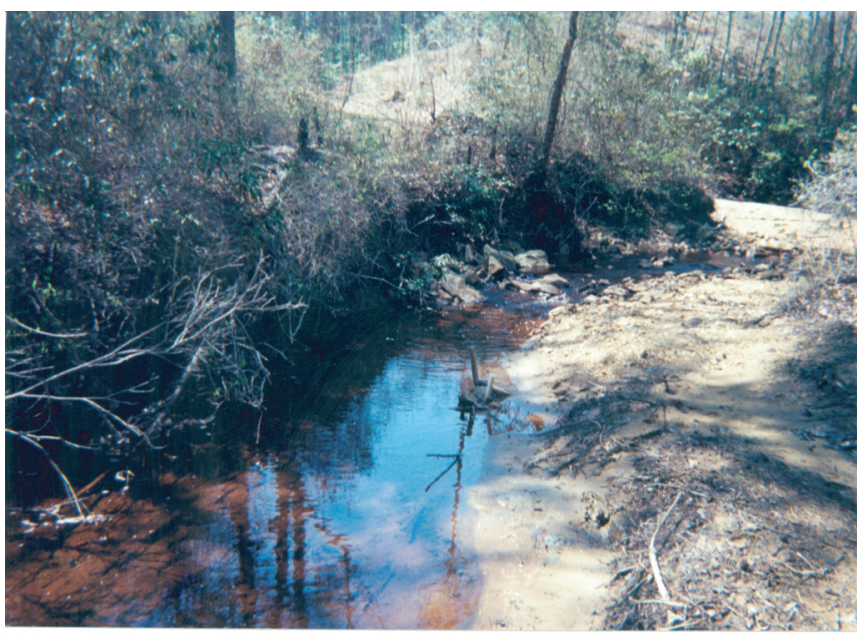

$D$

Figure 7. Site photographs of sediment accumulation experiment along Knights Branch. A, Placing the sampling media at site VLZN-13 upstream of the mine workings. $B$, Sample media placed near the tire in the middle of Knights Branch as it cut through tailings at site VLZN-4. Note pyrite in deltas along stream bank and red-orange color of floc. $C$, Sample media hanging from a wooden stake placed in the stream bank at site VLZN-3 at the downstream end of fluvial tailings deposit 1. D, Site VLZN-11, 4,000 m downstream of Valzinco.

transport and allowed to dry in air in the laboratory. Precipitates were scraped from the substrate surface and weighed. The surface area of the substrate was calculated on the basis of the geometry and dimensions of the substrate and combined with the mass of material deposited and the duration of the experiment (82 days) to estimate deposition rate as grams per square meter per day. Samples of streambed sediment collected at the start of the experiment and precipitates (for sufficiently large samples) were analyzed by XRD, ICP-AES, and ICP-MS.

\section{Weathering Experiments on Tailings}

A bulk sample of black unoxidized flotation tailings was collected along the Knights Branch streambank. The sample was placed on 325-mesh sieve cloth in a large open pan and exposed to natural weather conditions on the roof of the
USGS building in Reston, Va. The cloth allowed the "pile" to drain. Weather conditions were monitored, and the sample was checked intermittently over the course of several weeks to observe changes. Salts that accumulated during dry periods were sampled and identified by XRD and SEM.

\section{Study Results}

\section{Ore}

Metamorphosed volcanic rocks of the Chopawamsic Formation that host the Valzinco deposit were exposed in outcrop along Knights Branch at a bridge. Although no stockpiles of ore were present when this study was conducted, scattered 
pieces of ore float littered the site. Geochemical analysis of a representative sample of ore float (table $1 A$ ) shows that the ore is highly enriched in iron (54 wt percent) and zinc ( $7 \mathrm{wt}$ percent) with lesser amounts of copper, lead, and trace metals such as arsenic and cadmium. Pyrite is the dominant sulfide mineral in Valzinco ore. Microprobe data indicate that Valzinco pyrite contains a minor amount of cobalt $(0.18 \mathrm{wt}$ percent $\mathrm{Co}$ ), sphalerite is iron rich ( $8.6 \mathrm{wt}$ percent $\mathrm{Fe}$ ) with minor concentrations of cadmium and manganese $(0.21 \mathrm{wt}$ percent each), and chalcopyrite is essentially pure (table $1 B$ ).

Table 1A. Geochemistry of Valzinco ore.

\begin{tabular}{|c|c|c|c|c|c|}
\hline \multicolumn{6}{|c|}{ XRF data } \\
\hline $\mathrm{SiO}_{2}$ & wt percent & 1.28 & $\mathrm{~K}_{2} \mathrm{O}$ & wt percent & $<0.10$ \\
\hline $\mathrm{Fe}_{2} \mathrm{O}_{3}$ & wt percent & 60.6 & $\mathrm{TiO}_{2}$ & wt percent & $<0.04$ \\
\hline $\mathrm{MgO}$ & wt percent & 0.56 & $\mathrm{P}_{2} \mathrm{O}_{5}$ & wt percent & $<0.20$ \\
\hline $\mathrm{CaO}$ & wt percent & $<0.10$ & $\mathrm{MnO}$ & wt percent & 0.5 \\
\hline $\mathrm{Na}_{2} \mathrm{O}$ & wt percent & 3.01 & LOI & wt percent & 27 \\
\hline \multicolumn{6}{|c|}{ ICP-AES data } \\
\hline $\mathrm{Al}$ & wt percent & 0.13 & $\mathrm{Mn}$ & ppm & 4,800 \\
\hline $\mathrm{Ag}$ & ppm & 4.4 & Mo & ppm & 28 \\
\hline As & ppm & 62 & $\mathrm{Nd}$ & ppm & 1.1 \\
\hline $\mathrm{Ba}$ & ppm & 8.3 & $\mathrm{Ni}$ & ppm & 100 \\
\hline $\mathrm{Bi}$ & ppm & 0.26 & $\mathrm{~Pb}$ & ppm & 260 \\
\hline $\mathrm{Ca}$ & wt percent & 0.1 & $\mathrm{Sb}$ & ppm & 4.2 \\
\hline $\mathrm{Cd}$ & ppm & 160 & $\mathrm{Sn}$ & ppm & 33 \\
\hline Co & ppm & 450 & $\mathrm{U}$ & ppm & 0.32 \\
\hline $\mathrm{Cu}$ & ppm & 15,000 & $\mathrm{~V}$ & ppm & 7.2 \\
\hline $\mathrm{Fe}$ & wt percent & 54 & W & ppm & 0.61 \\
\hline $\mathrm{K}$ & wt percent & $<0.05$ & $\mathrm{Zn}$ & ppm & 69,000 \\
\hline $\mathrm{Mg}$ & wt percent & 0.62 & & & \\
\hline
\end{tabular}

Table 1B. Mineral chemistry (weight percent) by electron microprobe.

\begin{tabular}{|c|c|c|c|}
\hline Mineral & Pyrite (n=15) & Chalcopyrite $(n=3)$ & Sphalerite $(n=6)$ \\
\hline $\mathrm{Fe}$ & 47.6 & 30.4 & 8.64 \\
\hline $\mathrm{Cu}$ & 0.02 & 32.7 & 0 \\
\hline $\mathrm{Zn}$ & 0.01 & 0 & 57.9 \\
\hline Co & 0.18 & 0.04 & 0.06 \\
\hline Mn & 0 & 0 & 0.21 \\
\hline $\mathrm{Cd}$ & 0 & 0 & 0.21 \\
\hline S & 52.6 & 34.8 & 33.3 \\
\hline Total & 100 & 98 & 100.3 \\
\hline
\end{tabular}

\section{Valzinco Tailings}

Most of the mine waste at Valzinco consisted of very fine-grained $(<200$ mesh or $<70 \mu \mathrm{m})$ flotation mill tailings composed of pyrite, sphalerite, galena, chalcopyrite, magnetite, and silicate gangue minerals, including quartz, mica, feldspars, and chlorite (table 2). Pyrrhotite was noted in one of the auger samples. Modal analysis showed that pyrite constituted about 70 percent of the heavy mineral component of the tailings (fig. $8 A$ ). Sphalerite, galena, chalcopyrite, ilmenite, and zircon are also present. Pyrite grains have a maximum particle dimension of about $100 \mu \mathrm{m}$. The sulfate minerals jarosite and gypsum were identified in surface material by XRD; these minerals were not identified at depth in the piles. The only carbonate mineral identified at the site is siderite (fig. $8 B$ ). The upper tailings surfaces were oxidized by continuous exposure to air and water. The western end of spoil pile 1 (locality 1) appeared to be less oxidized than the eastern end of the pile (locality 2), perhaps because of the flow of acidic waters from the ore-processing facilities onto the eastern part of the pile. Despite the orange-red color of the tailings surfaces, no goethite or other iron oxyhydroxide minerals were detected by XRD.

Composite surface soil samples (table 3 ) from the western (fig. 3, sample SP1A) and eastern ends (fig. 3, sample SP1B) showed that the surface of the entire pile contained elevated concentrations of base metals, especially lead, and that the eastern end of the pile contained about 8 times as much zinc, 10 times as much cadmium, and twice as much

Table 2. Mineralogy of flotation tailings from Valzinco mine spoil pile 1.

[X, major constituent; tr, trace constituent, -, not present by powder XRD]

\begin{tabular}{|c|c|c|c|c|c|}
\hline \multirow[b]{2}{*}{ Sample } & \multicolumn{2}{|c|}{ Surface composites } & \multicolumn{3}{|c|}{ Auger samples } \\
\hline & $\begin{array}{c}\text { 99VLZN7- } \\
\text { Spoil 1A }\end{array}$ & $\begin{array}{c}\text { 99VLZN7- } \\
\text { Spoil 1B }\end{array}$ & $\begin{array}{c}\text { 99VLZN7- } \\
\text { 4A }\end{array}$ & $\begin{array}{l}\text { 99VLZN7- } \\
\text { 4B }\end{array}$ & $\begin{array}{l}\text { 99VLZN7- } \\
\quad \text { 4C }\end{array}$ \\
\hline Depth $(\mathrm{cm})$ & 0 & 0 & 20 & 122 & 200 \\
\hline Quartz & $\mathrm{X}$ & $\mathrm{X}$ & $\mathrm{X}$ & $X$ & $\mathrm{X}$ \\
\hline Chlorite & $\mathrm{X}$ & - & $\mathrm{X}$ & $\mathrm{X}$ & $\mathrm{X}$ \\
\hline Mica & $\mathrm{X}$ & $\mathrm{X}$ & $\mathrm{X}$ & $\mathrm{X}$ & $\mathrm{X}$ \\
\hline Feldspar & $\mathrm{X}$ & $\mathrm{X}$ & - & $\operatorname{tr}$ & - \\
\hline Pyrite & $\mathrm{X}$ & $\mathrm{X}$ & $\mathrm{x}$ & $\mathrm{X}$ & $\mathrm{X}$ \\
\hline Pyrrhotite & - & - & $\mathrm{x}$ & - & - \\
\hline Galena & $\mathrm{X}$ & $\mathrm{X}$ & - & $\mathrm{X}$ & $\mathrm{X}$ \\
\hline Sphalerite & $\mathrm{X}$ & $\mathrm{X}$ & $\mathrm{x}$ & $\mathrm{x}$ & $\mathrm{X}$ \\
\hline Magnetite & $\mathrm{X}$ & $\mathrm{X}$ & $\mathrm{x}$ & $\mathrm{x}$ & $\mathrm{X}$ \\
\hline Jarosite & $\mathrm{X}$ & - & - & - & - \\
\hline Gypsum & $\mathrm{X}$ & $\mathrm{X}$ & - & - & - \\
\hline Siderite & - & - & $\mathrm{X}$ & $\mathrm{X}$ & $\mathrm{X}$ \\
\hline Chalcopyrite & - & - & - & - & - \\
\hline
\end{tabular}



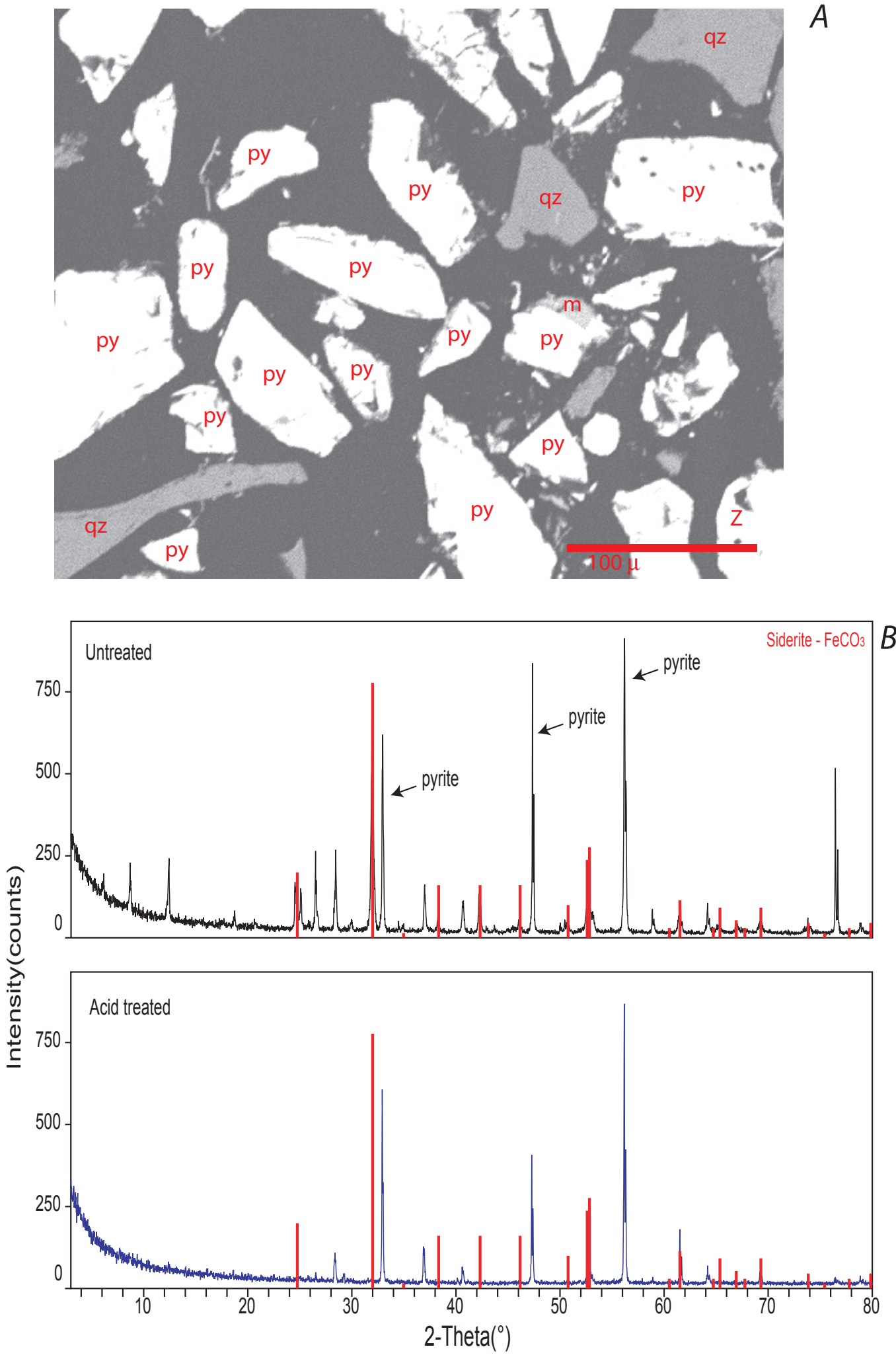

Figure 8. Valzinco mine tailings. $A$, Backscattered-electron SEM image of a heavy mineral separate showing size and shape of sulfide minerals (py, pyrite; q, quartz; $\mathrm{z}$, zircon; $\mathrm{m}$, mica). $B$, X-ray powder diffraction patterns of black flotation tailings sampled at a depth of $20 \mathrm{~cm}$ in spoil pile 1 (fig. 3, sample VLZN7-4). Siderite (peaks marked by red bars) in the original pattern (untreated) disappeared after digestion on $10 \% \mathrm{HCl}$ for 30 minutes (treated). Other peaks are pyrite, mica, and chlorite. Mica and chlorite peaks are diminished in intensity for the acid-treated sample. 
copper as the western end of the pile. Tailings sampled from the gully area (table 3 , locality 3 ) contained very high concentrations (1-2 percent) of zinc and lead as well as significant copper ( 0.2 percent). The extreme metal concentrations in the gully area and the very low $\mathrm{pH}$ waters that intermittently drained from it demonstrate that the area represented a "hot

Table 3. Selected geochemical data for Valzinco mine tailings.

\begin{tabular}{ccccccc}
\hline & \multicolumn{7}{c}{ Analysis $^{1}$} \\
\cline { 2 - 7 } $\begin{array}{c}\text { Ele- } \\
\text { ment }\end{array}$ & 1 & 2 & 3 & 4 & 5 & 6 \\
\hline
\end{tabular}

\begin{tabular}{|c|c|c|c|c|c|c|}
\hline \multicolumn{7}{|c|}{ Major elements (weight percent) } \\
\hline $\mathrm{Al}$ & 1.6 & 2.7 & 8.6 & 2.8 & 3.1 & 4.6 \\
\hline $\mathrm{Ca}$ & $<0.05$ & $<0.05$ & $<0.05$ & 0.08 & 0.06 & 0.05 \\
\hline $\mathrm{Fe}$ & 8 & 9.7 & 6.6 & 12 & 8.3 & 9.4 \\
\hline K & 0.79 & 0.98 & 2.4 & 0.89 & 1 & 1.6 \\
\hline $\mathrm{Mg}$ & 0.13 & 0.33 & 0.99 & 0.89 & 0.53 & 0.6 \\
\hline $\mathrm{Na}$ & 0.06 & 0.07 & 0.11 & 0.12 & 0.05 & 0.09 \\
\hline \multicolumn{7}{|c|}{ Minor and trace elements (parts per million) } \\
\hline $\mathrm{Ag}$ & 8.1 & 4.9 & 13 & 3.6 & 7.3 & 8.7 \\
\hline As & 46 & 29 & 21 & 29 & 19 & 28 \\
\hline $\mathrm{Ba}$ & 140 & 180 & 470 & 150 & 180 & 310 \\
\hline $\mathrm{Cd}$ & 0.4 & 4.5 & 110 & 25 & 13 & 20 \\
\hline Co & 67 & 44 & 43 & 85 & 48 & 62 \\
\hline $\mathrm{Cr}$ & 5 & 10 & 41 & 18 & 10 & 16 \\
\hline $\mathrm{Cu}$ & 280 & 510 & 2,000 & 680 & 660 & 910 \\
\hline $\mathrm{Mn}$ & 740 & 520 & 600 & 1000 & 800 & 920 \\
\hline $\mathrm{Ni}$ & 4 & 6.7 & 26 & 25 & 14 & 16 \\
\hline $\mathrm{Pb}$ & 4,000 & 4,100 & 16,000 & 2,400 & 6,200 & 8,100 \\
\hline $\mathrm{Sb}$ & 9.3 & 8.4 & 21 & 5.5 & 8.4 & 12 \\
\hline $\mathrm{Tl}$ & 0.75 & 0.8 & 1.9 & 0.95 & 0.9 & 1.2 \\
\hline $\mathrm{Zn}$ & 230 & 1,800 & 21,000 & 5,400 & 4,500 & 6,800 \\
\hline \multicolumn{7}{|c|}{ Other elements (weight percent) } \\
\hline Total S & 6.08 & 4.66 & 6.49 & 8.4 & 4.8 & 6.31 \\
\hline Total C & 0.11 & 0.7 & 0.07 & 0.44 & 0.45 & 0.47 \\
\hline $\begin{array}{c}\text { Organic } \\
\quad \mathrm{C}\end{array}$ & 0.11 & 0.67 & 0.07 & 0.07 & 0.11 & 0.09 \\
\hline
\end{tabular}

${ }^{1}$ Analysis key

1 99VLZN7-SP1A: Composite sample of surface material from western end of spoil pile 1

2 99VLZN7-SP1B: Composite sample of surface material from eastern end of spoil pile 1

3 VLZN7-2: Auger sample (50 to $102 \mathrm{~cm}$ interval) from eastern wall of tailings embankment in gully of former process water pond area

4 99VLZN7-4A: Sample from $20 \mathrm{~cm}$ depth in a hole dug in western end of spoil pile 1

5 99VLZN7-4B: Sample from $122 \mathrm{~cm}$ depth in a hole dug in wesernt end of spoil pile 1

6 99VLZN7-4C: Sample from $160 \mathrm{~cm}$ depth in a hole dug in western end of spoil pile 1 spot" (anomalous area). Spoil pile 1 was over $200 \mathrm{~cm}$ thick; at a depth of a few centimeters, the tailings were black and unoxidized and, during a hot and dry period during the summer of 1999, were water saturated at a depth of $120 \mathrm{~cm}$. Geochemical data for three samples collected at depths of 20,122, and $160 \mathrm{~cm}$ from in a hole dug into spoil pile 1 (fig. 3, sample VLZN7-4) showed that base metals tended to increase with depth, although base-metal concentrations here are lower than they are in the gully area. Low paste-pH values for surface soil samples $(\mathrm{pH}<3)$ reflected the readily available acidity in the tailings. Total carbon concentrations are less than $1 \mathrm{wt}$ percent. For surface composites and the gully sample (table 3, 1-3), essentially all of the carbon is present as organic carbon. For the samples from depth (table 3,4-6), most of the carbon is inorganic carbon incorporated in siderite. Total sulfur concentrations in tailings range from 4.6 to $8.8 \mathrm{wt}$ percent (tables 3 , 4). Sulfur determinations measured by three different laboratories as part of the acid-base accounting analyses (table 4) are in good agreement with each other and with the sulfur concentrations reported in table 3 . Sulfate sulfur represents about 10 to $30 \mathrm{wt}$ percent of the total sulfur present in the surface composites and less than $1 \mathrm{wt}$ percent of the total sulfur in the tailings at depth. The chemistry reflects the sample mineralogy - that is, the sulfate minerals gypsum and jarosite were observed in the surface composites but not in the tailings from depth (table 2).

Acid-base accounting indicates that the surface composites lacked any inherent neutralization potential $(\mathrm{NP}<0)$, had high acid-producing potential ( $\mathrm{AP}>100 \mathrm{~kg} \mathrm{CaCO}_{3} /$ tonne), negative net neutralization potential (NNP), and NP/AP ratios $<1: 1$. All of these measures indicate that the samples are ranked as likely to generate acid by any accepted guidelines (Price and others, 1997; Jambor and Blowes, 1998). Samples collected within the tailings pile also had high AP but variable NPs ranging from positive to negative values depending on the laboratories and methods used. NP results determined by three different methods by the same laboratory (table 4, Methods C, D, E) are most variable for the siderite-bearing samples. The large discrepancy between NP values reported for Method A and the others is not understood, although a smaller sample size used for Method A may be a factor. Although siderite is a carbonate mineral, it is well known that siderite may not contribute to acid neutralization; therefore, $\mathrm{CO}_{2}$ reported in NP determinations may overestimate actual NP (Jambor and Blowes, 1998). Regardless of the method or the laboratory, all the Valzinco samples are net acidic by all accepted criteria, and samples analyzed for this study are worse (more negative NNP) than the composite sample used for preliminary lime requirement calculations for site reclamation (table 4, MVTI sample).

\section{Fluvial Tailings}

The dominant minerals in the three fluvial tailings deposits are quartz, mica, and chlorite. Sandy, buff- to orangecolored mottled material forms a shallow surface layer a few 
Table 4. Acid-base accounting data for Valzinco tailings.

[AP, acid-generating potential; NP, neutralization potential; NNP, net neutralization potential. AP, NP, and NNP reported as kg CaCO $/$ tonne. MVTI, Composite sample provided by VDMME for lime requirement calculations for site reclamation (MVTechnologies, Inc., 1998); SDO-1 is a USGS reference sample (Devonian Ohio Shale) that contains $5.35 \pm 0.44$ wt percent total S]

\begin{tabular}{|c|c|c|c|c|c|c|c|c|c|}
\hline Sample & Method $^{1}$ & Paste pH & Total S wt percent & Sulfide S wt percent & Sulfate S wt percent & AP & NP & NNP & NP/AP \\
\hline MVTI & & 3.17 & 4.7 & 3.33 & 1.3 & 104 & -9.2 & -113 & 0.1 \\
\hline \multirow[t]{3}{*}{ 99VLZN7-SP1A } & A & 2.39 & 6 & 5.52 & 0.48 & 173 & -58 & -231 & 0.3 \\
\hline & $\mathrm{C}$ & 2.2 & 6.03 & 4.93 & 1.1 & 154 & -16 & -170 & 0.1 \\
\hline & $\mathrm{D}$ & 2.2 & 6.03 & 4.93 & 1.1 & 154 & 0 & -154 & 0 \\
\hline \multirow[t]{4}{*}{ 99VLZN7-SP1B } & A & 3.02 & 4.75 & 3.75 & 1 & 117 & -57 & -174 & 0.5 \\
\hline & $\mathrm{B}$ & 3.1 & 4.75 & 3.86 & 0.89 & 121 & -14 & -135 & 0.1 \\
\hline & $\mathrm{C}$ & 2.4 & 5.04 & 4.4 & 0.64 & 138 & -12 & -149 & 0.1 \\
\hline & $\mathrm{D}$ & 2.4 & 5.04 & 4.4 & 0.64 & 138 & 0 & -138 & 0 \\
\hline \multirow{2}{*}{ 99VLZN7-4A } & $\mathrm{D}$ & 4 & 8.76 & 8.58 & 0.18 & 268 & 17 & -251 & 0.1 \\
\hline & $\mathrm{E}$ & 4 & 8.76 & 8.58 & 0.18 & 274 & -2 & -276 & 0 \\
\hline \multirow[t]{4}{*}{ 99VLZN7-4B } & A & 4.82 & 4.9 & 4.85 & 0.05 & 152 & -45 & -196 & 0.3 \\
\hline & $\mathrm{C}$ & 4.5 & 4.94 & 4.82 & 0.12 & 151 & 5 & -145 & 0 \\
\hline & $\mathrm{D}$ & 4.5 & 4.94 & 4.82 & 0.12 & 151 & 9 & -142 & 0.1 \\
\hline & $\mathrm{E}$ & 4.5 & 4.94 & 4.82 & 0.12 & 154 & 11 & -143 & 0.1 \\
\hline \multirow[t]{2}{*}{ 99VLZN7-4C } & A & 4.34 & 6.3 & 6.2 & 0.1 & 194 & -44 & -238 & 0.2 \\
\hline & $\mathrm{C}$ & 4 & 6.54 & 6.27 & 0.27 & 196 & 4 & -192 & 0 \\
\hline SDO-1 & $\mathrm{E}$ & 3.3 & 5.54 & 4.67 & 0.87 & 173 & -5 & -178 & 0 \\
\hline
\end{tabular}

${ }^{1}$ Methods: A, Modified Sobek method, Activation Laboratories, Inc.; B, Modified Sobek method, Chemex Labs; C, Modified Sobek method NP, BC Research, Inc.; D, BCR method for NP, BC Research, Inc. (AP based on sulfide S); E, Sobek method NP, BC Research, Inc. (AP based on total S)

centimeters thick. Pyrite is present in black tailings beneath, and interlayered with, the sandy material and organic matter. At fluvial tailings deposits 2 and 3 downstream from the Valzinco mine site, grayish-green plastic underclay is present at depth beneath the fluvial deposits. This clay is exposed along the stream channel at fluvial tailings deposit 2 . The stratigraphy of fluvial tailings deposit 3 was examined by taking auger samples across the center of the deposit at 5-m intervals from the stream (fig. 3, A) to the marshy area west of the deposit (fig. 3, J). Black pyritic tailings are thickest near the stream and thin towards the west (fig. 9). Pyrite, magnetite, chalcocite, covellite, and marcasite are identified in heavy mineral separates of the black material in addition to the silicate minerals quartz, chlorite, and albite. The presence of an organic horizon at depth below sandy orange and mottled sediment suggests that stream sediment was deposited over organic horizons that existed in the soil profile before a flood event.

A 0.1-L (4-oz ) cup of black unoxidized tailings was collected from fluvial tailings deposit 3 at a depth of 10 to 25 $\mathrm{cm}$. The sample was wet sieved into size fractions, air dried, and weighed. The bulk of the sample (72 percent) contained particles less than $0.125 \mathrm{~mm}$ in diameter (sand, silt, and clay). A split of the 0.125- to 0.038-mm (120- to 400-mesh) material was placed in methylene iodide to concentrate heavy minerals. 


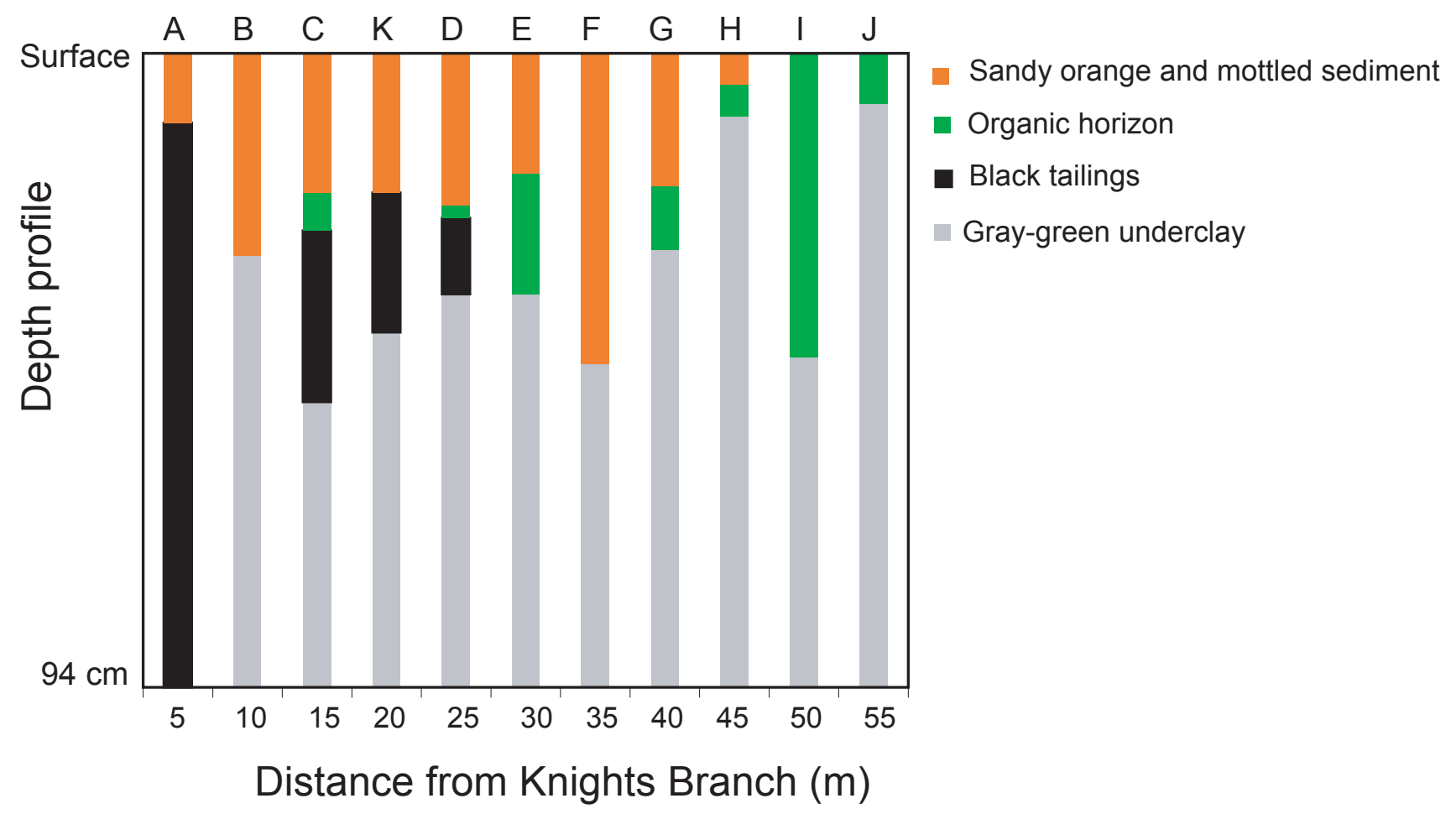

Figure 9. Schematic cross-section of fluvial tailings deposit 3 (downstream of the Mitchell mine) showing the stratigraphy of the deposit from streamside (A) to a boggy area $(\mathrm{J})$ at the edge of the clearing (see fig. 3). Classification is based on visual inspection of auger cores samples at 5 -m intervals across the width of the deposit.

Heavy minerals comprised about 1 wt percent of the sample and included pyrite, magnetite, and secondary copper sulfide minerals. Qualitative XRF analysis of the heavy mineral separate confirmed iron, copper, lead, zinc, manganese, titanium, and sulfur.

Fluvial tailings mimic the lead- and zinc-rich geochemical signature of the flotation tailings, but concentrations are less extreme, and near-surface parts of the fluvial deposits tend to carry higher metal concentrations than deeper samples (table 5). For example, an auger sample from a depth of 20 $\mathrm{cm}$ in the center of fluvial tailings deposit 1 had 4,400 ppm $\mathrm{Zn}$ and 1,100 ppm Pb whereas a sample from a depth of 122 $\mathrm{cm}$ at the same location had $160 \mathrm{ppm} \mathrm{Zn}$ and $210 \mathrm{ppm} \mathrm{Pb}$. Surface composites of fluvial tailings deposits 2 and 3 (table 5 , samples 3,8 ) each contain $>2,500 \mathrm{ppm}$ total base metals, most of which is lead. Mercury concentrations in all samples from fluvial tailings deposit 2 are $\leq 0.1 \mathrm{ppm}$; mercury concentrations range from 0.1 to $0.32 \mathrm{ppm}$ in samples from fluvial tailings deposit 3, which is downstream of the Mitchell mine, where mercury was likely used for gold processing. None of the mercury values exceed the EPA preliminary remediation goals for residential soils of $23 \mathrm{mg} / \mathrm{kg}$ (ppm) for mercury and mercury compounds. Samples from all three fluvial tailings deposits exceed the EPA's preliminary remediation goals for residential soils for lead (>400 ppm).

The gray-green underclay (table 5, samples $7,11,14$ ) generally contains lower iron and metal concentrations than the overlying fluvial material. A background soil sample collected below the organic horizon in a wooded area adjacent to fluvial tailings deposit 3 is geochemically similar to the underclay material (table 5, sample 15), with the exception of mercury. The relatively high mercury concentration $(0.2$, $0.3 \mathrm{ppm}$ ) in the clay suggests that mercury may have leached through the deposit and sorbed to the clay. Copper, lead, and zinc concentrations in the background soil are elevated relative to Shacklette and Boerngen's (1984) data for mean concentrations of these metals in soils from the eastern United States (table 5).

\section{Comparison of Valzinco Mine Tailings with Downstream Fluvial Tailings}

Total base-metal concentrations in flotation tailings at the Valzinco mine range from about 4,500 to $85,000 \mathrm{ppm}$ (fig. 10). Lead and zinc are the dominant base metals present with $\mathrm{Pb} \geq \mathrm{Zn}>\mathrm{Cu}$. Samples from the various fluvial deposits contain total base-metal concentrations ranging from 323 to 6,160 ppm (table 5, fig. 10). Background soil contains less than 300 ppm base metals, and gray-green clayey soils that underlie the fluvial deposits contain less than 1,000 ppm base metals. Metal contents of the fluvial deposits are lower than those of tailings at the Valzinco mine site; however, the fluvial deposits all contain lead in excess of preliminary remediation goals for soils ( $400 \mathrm{ppm}$ for residential soils, $750 \mathrm{ppm}$ for industrial soils). These data indicate that the fluvial deposits warrant consideration for capping or removal in any future reclamation activities along Knights Branch. 


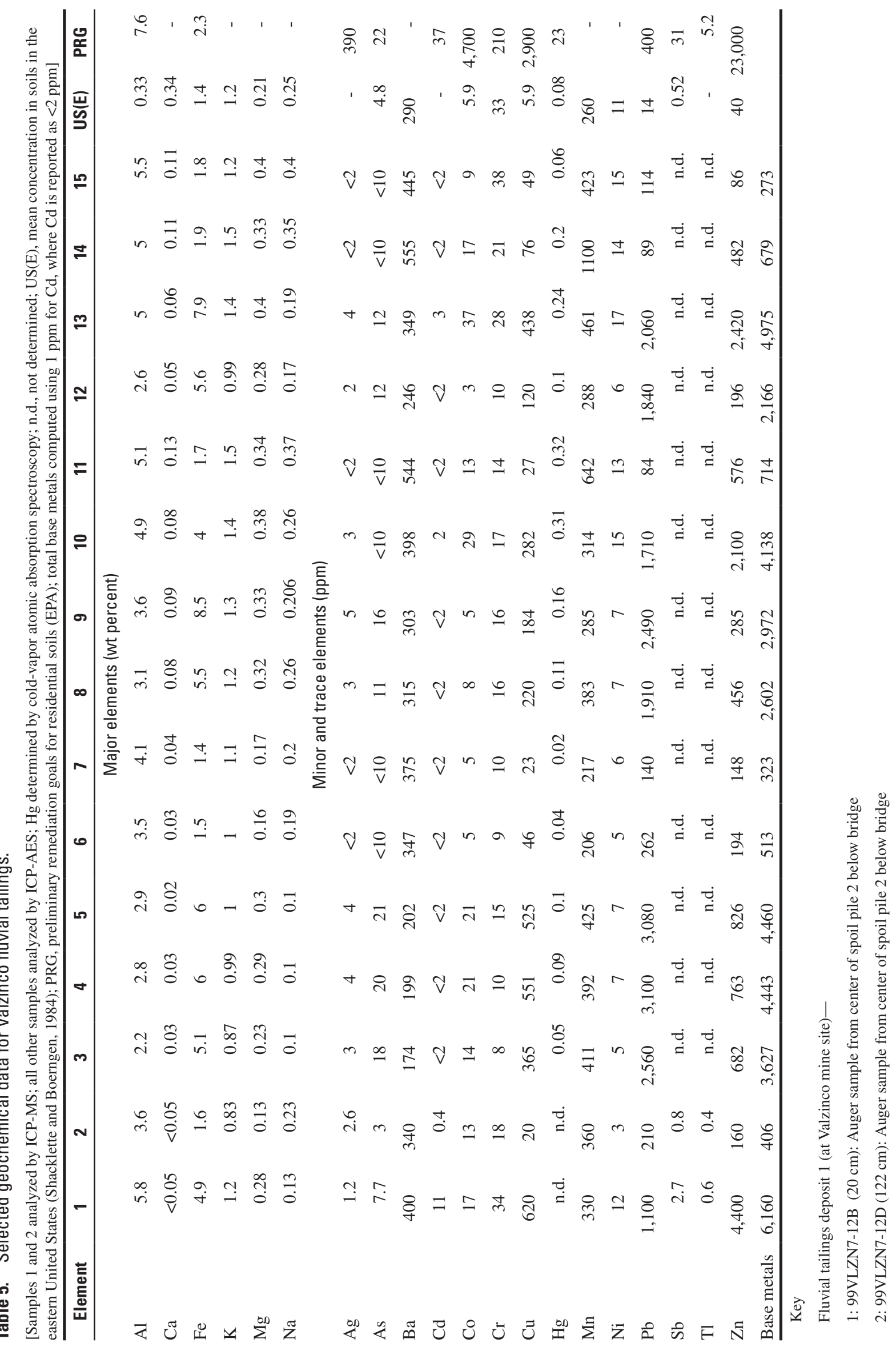




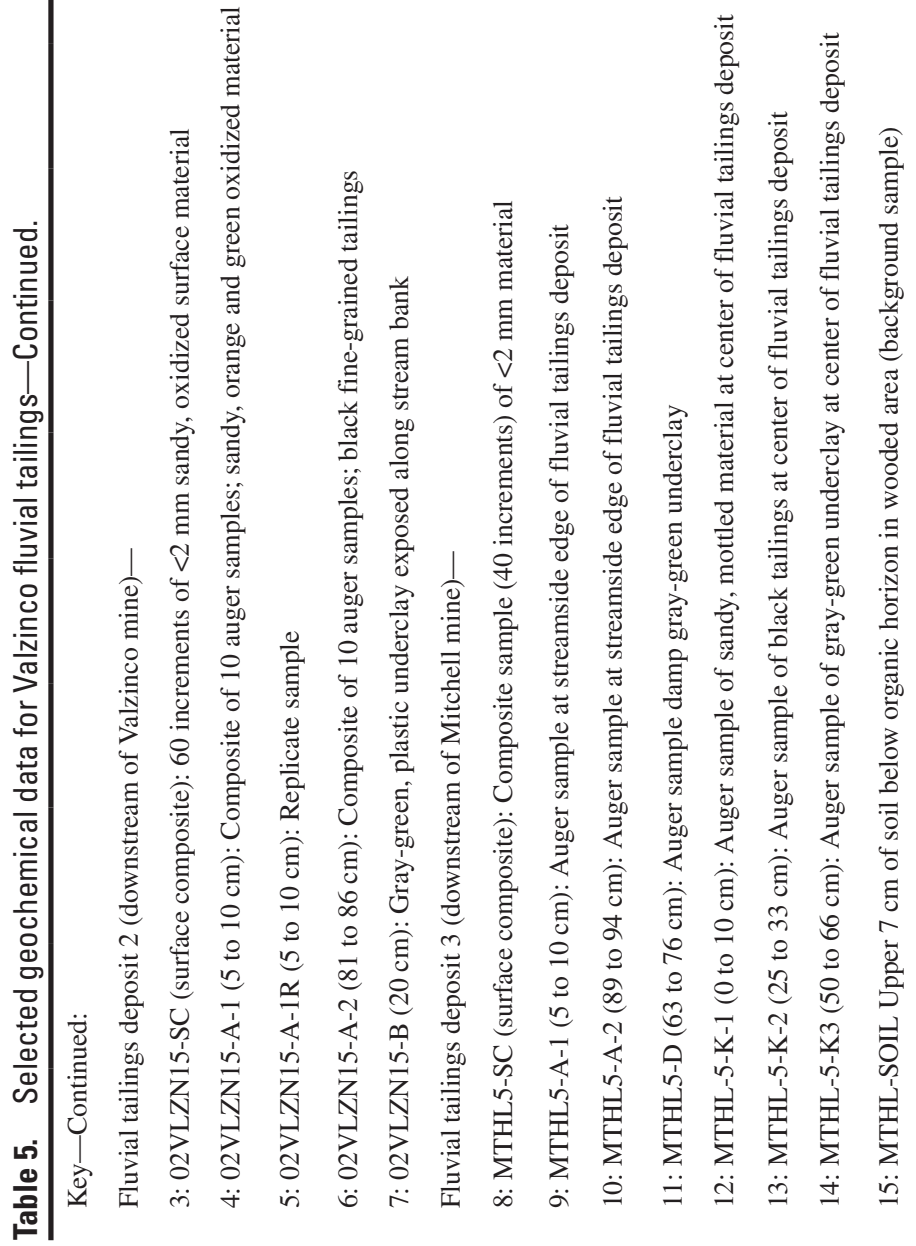




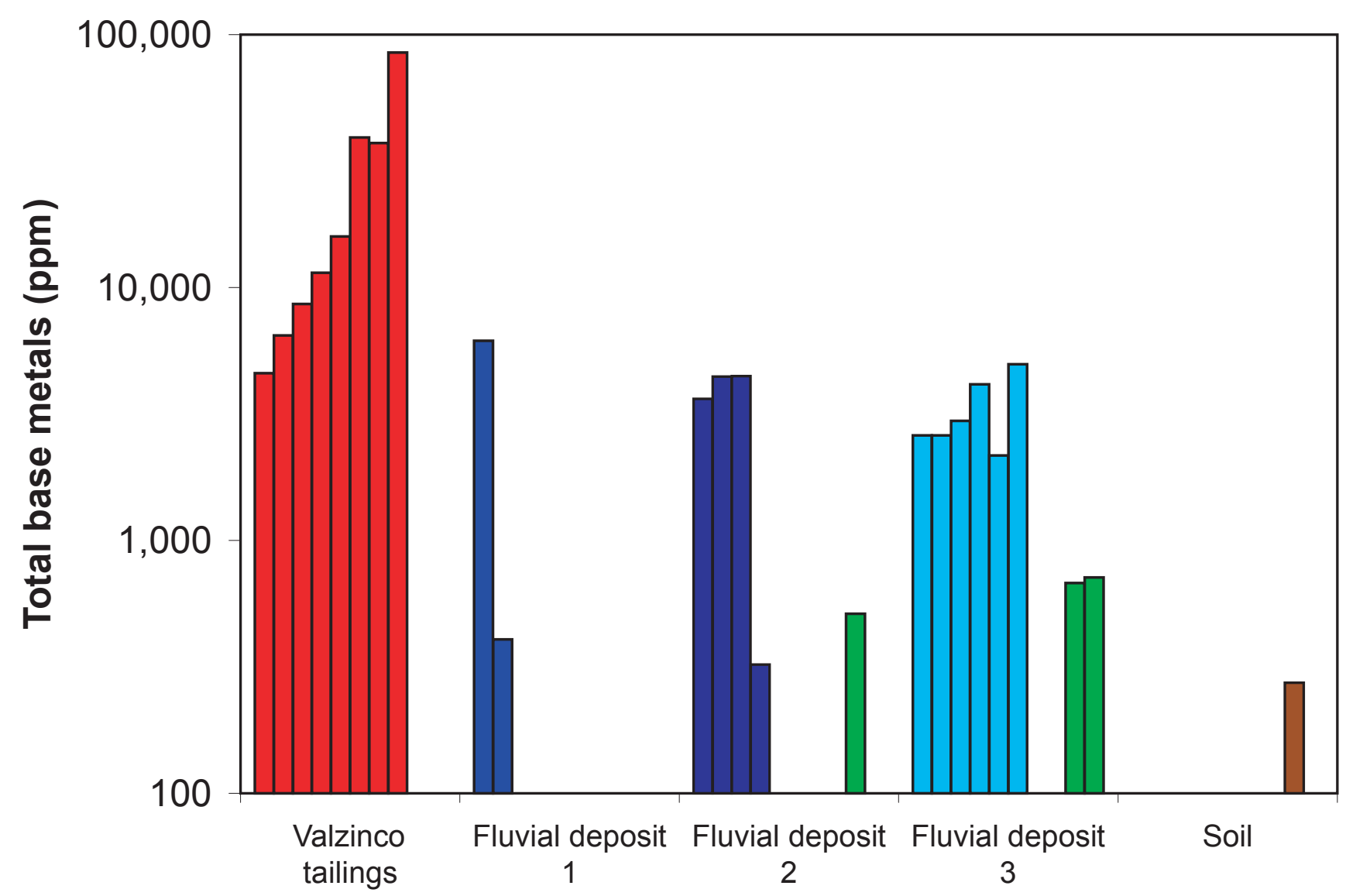

Figure 10. Bar chart comparing total base-metal concentrations $(\mathrm{Cu}+\mathrm{Co}+\mathrm{Cd}+\mathrm{Ni}+\mathrm{Pb}+\mathrm{Zn})$ in Valzinco mine tailings, downstream fluvial deposits, and background soil. Each bar represents a separate sample. Gray-green underclay at fluvial deposits 2 and 3 is shown as green bars. Samples include surface composites as well as subsurface samples.

Mercury was not known to be a concern at the start of this study, so it was not included in analyses of the Valzinco tailings or fluvial deposit 1 . Comparison of mercury data for fluvial deposits 2 and 3, however, provides an indication of the influence of the Mitchell mine on downstream deposits. The abundant quartz litter on fluvial deposit 3 suggests that the site was used for working Mitchell ores or, alternatively, that quartz was carried downstream from the Mitchell site and deposited there during storm events. Mercury concentrations in fluvial tailings from deposit 2 (upstream of Mitchell) range from 0.02 to $0.1 \mathrm{ppm}$ (table 5). Mercury concentrations in deposit 3 are consistently higher (0.1-0.3 ppm). Thus, fluvial deposit 3 apparently contains material contributed by both mines.

\section{Mitchell Mine Pond Sediments}

Sediments at the bottom of two of the ponds at the Mitchell mine site were sampled to check for mercury and other metals. The sediments are mainly composed of quartz, muscovite, kaolinite, and feldspar. Chlorite and pyrite are present in the upper $8 \mathrm{~cm}$ of sediment in the small pond (water sample site MTHL7). Mercury was detected in all of the samples in concentrations ranging from 0.3 to $1.5 \mathrm{ppm}$ (table 6 ). Results for mercury for samples placed in I-CHEM jars are comparable but slightly higher in concentration than the mercury values determined in the other sample split. Mercury concentrations decrease from $0.65 \mathrm{ppm}$ in the upper, organic-rich $2.5 \mathrm{~cm}$ of core extracted from the small pond to $0.3 \mathrm{ppm}$ in the 5 - to $8-\mathrm{cm}$ section of core. The deeper parts of the core $(10-20 \mathrm{~cm})$ contained higher concentrations of mercury (1.2 ppm). Arsenic and base-metal concentrations are elevated in the sediment from the small pond (MTHL-7) relative to concentrations measured in the larger pond (MTHL-6). Lead (up to 3,500 ppm), zinc (up to 1,730 ppm), and copper (up to $610 \mathrm{ppm}$ ) concentrations suggest that Valzinco mine tailings are probably incorporated in the pond sediment. However, heavy mineral separates from pond sediment did not yield any pyrite or other sulfide minerals. The mercury zoning in the sediment suggests that mercury that washed into the ponds during the mining era sank and was covered by later influxes of sediment. Water samples from the large pond contain about 10 times as much total mercury as water samples from the small pond and the highest mercury concentrations $(100 \mathrm{ng} / \mathrm{L})$ of any of the water samples tested (R.R. Seal, written communication, 2004; Seal and others, in preparation). The large pond sediment was sampled near the edge owing to difficult access and water depth. Sampling of sediment at depth at the center of the large pond might reveal concentrations of sediment mercury comparable to or even higher 
Table 6. Selected geochemical data for Mitchell mine pond sediments.

[Hg 1(I-CHEM jar) and 2 (bulk sample) analyzed by cold-vapor atomic absorption spectroscopy; all other samples analyzed by ICP-AES; n.d., not determined; PEC, consensus-based probable effects concentration (MacDonald and others, 2000)]

\begin{tabular}{|c|c|c|c|c|c|c|c|}
\hline \multirow[b]{2}{*}{ Element } & \multirow[b]{2}{*}{ Units } & \multicolumn{6}{|c|}{ Sample $^{1}$} \\
\hline & & MTHL-6 & MTHL-7A & MTHL-7B & MTHL-7C & MTHL-7D & PEC \\
\hline $\mathrm{Hg}(1)$ & ppm & 0.38 & 0.73 & 0.33 & 1.52 & n.d. & 1.06 \\
\hline $\mathrm{Hg}(2)$ & ppm & 0.25 & 0.65 & 0.3 & 1.23 & 1.24 & \\
\hline $\mathrm{Al}$ & wt $\%$ & 5.4 & 4.3 & 5.5 & 5.4 & 6.1 & \\
\hline $\mathrm{Ca}$ & wt $\%$ & 0.08 & 0.06 & 0.04 & 0.07 & 0.07 & \\
\hline $\mathrm{Fe}$ & wt $\%$ & 1.83 & 13.8 & 8.07 & 3.98 & 4.35 & \\
\hline $\mathrm{K}$ & wt $\%$ & 1.99 & 1.47 & 1.94 & 1.54 & 1.68 & \\
\hline $\mathrm{Mg}$ & wt $\%$ & 0.58 & 0.41 & 0.53 & 0.36 & 0.37 & \\
\hline $\mathrm{Na}$ & wt $\%$ & 0.59 & 0.15 & 0.15 & 0.25 & 0.28 & \\
\hline $\mathrm{Ag}$ & ppm & $<2$ & 7 & 9 & 3 & 2 & \\
\hline As & ppm & $<10$ & 18 & 21 & $<10$ & $<10$ & 33 \\
\hline $\mathrm{Ba}$ & ppm & 675 & 322 & 404 & 514 & 557 & \\
\hline $\mathrm{Be}$ & ppm & 2 & 2 & 2 & 2 & 2 & \\
\hline $\mathrm{Cd}$ & ppm & $<2$ & $<2$ & 4 & $<2$ & $<2$ & 4.98 \\
\hline Co & ppm & 7 & 8 & 16 & 8 & 6 & \\
\hline $\mathrm{Cr}$ & ppm & 14 & 27 & 24 & 35 & 35 & 111 \\
\hline $\mathrm{Cu}$ & ppm & 75 & 336 & 610 & 303 & 194 & 149 \\
\hline $\mathrm{Mn}$ & ppm & 191 & 256 & 310 & 173 & 162 & \\
\hline $\mathrm{Ni}$ & ppm & 11 & 10 & 10 & 12 & 14 & 48.6 \\
\hline $\mathrm{Pb}$ & ppm & 144 & 2,030 & 3,500 & 1,270 & 673 & 128 \\
\hline V & ppm & 56 & 71 & 94 & 65 & 69 & \\
\hline \multirow[t]{3}{*}{$\mathrm{Zn}$} & ppm & 260 & 708 & 1,730 & 825 & 363 & 459 \\
\hline & & \multicolumn{6}{|c|}{ Mean PEC quotient } \\
\hline & & 0.5 & 3.5 & 6.2 & 2.6 & 1.5 & \\
\hline
\end{tabular}

${ }^{1}$ MTHL-6: Big pond bottom material near pond outlet sampled with U-Dig-It

MTHL-7A: Small pond split spoon core sample; upper $2.5 \mathrm{~cm}$ of organic debris

MTHL-7B: Small pond split spoon core 5 to $8 \mathrm{~cm}$ brown/orange/black soil below organic debris

MTHL-7C: Small pond split spoon core soil and gray/green mottled clayey layer at $10 \mathrm{~cm}$ and below

MTHL-7D: Small pond core sample of bottom material sampled at $20 \mathrm{~cm}$

than those observed for the small pond. If tailings are present in the small pond, it seems likely that tailings are also present in the other ponds at the Mitchell mine site.

Pond-sediment quality is evaluated by comparing measured concentrations against consensus-based probable effects concentrations (PEC) established as stream-sediment quality guidelines for freshwater aquatic ecosystems. PEC- the concentration of an element above which harmful effects are likely to occur - is based on data matching sediment chemistry with toxicity data from field studies (MacDonald and others, 2000). Mean PEC quotients evaluate the combined effects of multiple contaminants in a sediment. The mean PEC quotient is computed by dividing each concentration by the appropri- ate PEC, summing the quotients, and normalizing the sum to the number of PEC quotients used for the sample. MacDonald and others (2000) showed that the mean PEC quotient correlated with incidence of toxicity; PEC quotients greater than 0.5 correlated with a high incidence of toxicity by multiple contaminants. Mean PEC quotients for the Mitchell mine pond sediments are greater than or equal to 0.5 , suggesting that the pond sediment is inhospitable to benthic organisms.

\section{Stream Sediments}

Stream sediments are composed mainly of quartz, muscovite, chlorite, and clay minerals. Pyrite is detected in 
the Knights Branch sediments as far downstream as fluvial tailings deposit 3. Pyrite was not apparent in sediment at the sample site farthest downstream from the Valzinco mine (MTHL-5-SS).

Selected geochemical data for stream sediments are compiled in table 7, along with mean PEC quotients. Background samples were collected at water sample sites along Music Branch and along a tributary to Knights Branch downstream of the Mitchell mine. For all background samples, mercury is below detection limits, and mean PEC quotients are all less than 0.5. Stream sediments along Knights Branch all exceeded PECs for lead (>128 ppm) by a factor of 5 or more (fig. 11). Mean PEC quotients all exceed 0.5 but generally decrease with increasing distance downstream from the Valzinco mine. Mercury ranged from 0.04 to $0.09 \mathrm{ppm}$; the highest concentration was found near the headwaters of Knights Branch where the stream cut through tailings. Mercury increases from 0.04 ppm upstream of the Mitchell mine to $0.06 \mathrm{ppm}$ downstream of the mine. However, the highest mercury concentration observed in any stream sediment was at the Valzinco mine before reclamation. None of the samples exceed the mercury PEC (1.06 ppm).

The Mitchell mine study was conducted after reclamation at Valzinco. Knights Branch was sampled at the Valzinco mine (table 7, analyses 4, 5) and 1,200 m downstream (table 7 , analysis 8) before reclamation (fig. 11, open symbols). Two of these sites were resampled post-reclamation when the other samples were collected. Thus, analyses 5 and 6 and 8 and 9 represent pre- and post-reclamation sediment analyses at the same locations. These pairs of analyses indicate marked decreases in lead, zinc, and copper between the two sampling events (fig. 11). For example, at the site 1,200 m downstream of Valzinco, lead decreased from 1,340 to $875 \mathrm{ppm}$, and zinc decreased from 1,430 to $300 \mathrm{ppm}$. These decreases are likely due to tailings removal and influxes of clean sediment. Erosion from fluvial tailings deposit 3 does not appear to have had any significant impact on Knights Branch stream sediments because sediment at site MTHL-5 (downstream of fluvial tailings deposit 3) has base-metal concentrations comparable to or lower than those of the samples collected immediately upstream of fluvial tailings deposit 3 (fig. 11). However, lead concentration and the mean sediment PEC quotient at MTHL5 indicate that inhospitable conditions exist. Sediment at this site might be diluted by the influx of uncontaminated sediment from a tributary.

\section{Sediment Accumulation Experiments}

Oxidative weathering of pyrite and other minerals in the Valzinco tailings released iron, sulfur, and other metals to the environment. During wet/dry cycles, efflorescent sulfate salts formed on the tailings. Dissolution of these salts during rain events provided metal-rich surface runoff to Knights Branch. Oxidation and hydrolysis of dissolved iron lead to precipitation of iron oxyhydroxide minerals and decreased $\mathrm{pH}$ in Knights Branch by reaction (1).

$$
\mathrm{Fe}^{3+}{ }_{(\mathrm{aq})}+3 \mathrm{H}_{2} \mathrm{O}_{(\mathrm{l})} \leftrightarrow \mathrm{Fe}(\mathrm{OH})_{3(\mathrm{~S})}+3 \mathrm{H}_{(\mathrm{aq})}^{+}(1)
$$

The bright red, orange, and yellow colors of ochreous precipitates that characterize AMD-impacted streams reflect the presence of iron-oxyhydroxide minerals (ferrihydrite, goethite) and iron- hydroxysulfate minerals (schwertmannite, jarosite). Because of their small particle size and high surface area, these minerals can sequester metals in solid phases. The sediment accumulation experiment was conducted to estimate the rate of accumulation of these precipitates and evaluate the role of precipitated sediments in sequestering metals. Sample media at some sites were not always completely submerged owing to fluctuating stream levels during the course (82 days) of the experiment. Sediment accumulated on submerged wooden dowels at each site indicated accumulation rates of about less than 1 to as much as $10 \mathrm{~g} / \mathrm{m}^{2} /$ day, the highest rate of accumulation being at site VLZN-4 where Knights Branch flowed through Valzinco tailings. Material adhering to the dowels included precipitated ochre as well as entrained detrital sediment. Samples collected with a syringe at the beginning of the experiment represent the uppermost floc at the water/ sediment interface. Despite the reddish ochre color of the sediments in the mine area, detrital silicate minerals (quartz, mica, chlorite, and kaolinite) comprise the bulk of the samples. Sample VLZN-13 represents the natural sediment sampled upstream of the mine workings in the marshy headwaters of Knights Branch. Pyrite and jarosite were detected in the streambed sediments at water sample sites VLZN-4 (in tailings) and VLZN-3 (downstream end of fluvial tailings deposit 1) and in yellow precipitate (sample 01VLZN6) sampled in a pH 2.7 seep from tailings along the edge of Knights Branch. Low peak-to-noise ratios and high backgrounds for XRD patterns of samples VLZN-4 and VLZN-3 indicate a high percentage of very poorly crystalline or amorphous material. Examination of the flocs collected with a syringe on February 7, 2001, under a microscope showed evidence of iron-oxyhydroxide or iron-hydroxysulfate minerals as well as diatoms, protists, and iron bacteria (Siderocapsa); the yellow-green algae Synura was observed only upstream of the mine site (E. Robbins, written communication, 2001).

Selected geochemical data for the starting and accumulated sediments are reported in table 8. Accumulated sediments deposited on different substrates are chemically similar (fig. 12A, $B$, appendix). Comparing the geochemistry of flocs sampled at the three sites affected by mining (VLZN4, VLZN-3, VLZN-11) at the beginning of the experiment (February 7, 2001) with accumulated sediment shows that (1) the iron concentrations of the sediments in the mine area and downstream are much higher than those in the headwaters sediment, (2) the floc sampled at the beginning of the experiment at VLZN-4 contained more iron (20 wt percent Fe) than the accumulated sediments (12 to 15 wt percent Fe), (3) the accumulated sediments at the downstream sample sites contained higher iron concentrations than the flocs sampled at those sites, and (4) the accumulated sediments in all sample substrates $(\mathrm{A}, \mathrm{B}, \mathrm{C})$ at the three sites affected by mining 
Table 7. Selected geochemical data for Knights Branch and background stream sediments

[Hg analyzed by cold-vapor atomic absorption spectroscopy; all other samples analyzed by ICP-AES; n.d., not determined; PEC (in parentheses for selected elements) and mean PEC-quotient based on MacDonald and others, 2000]

\begin{tabular}{|c|c|c|c|c|c|c|c|c|c|c|c|c|}
\hline \multirow[b]{2}{*}{ Element } & \multicolumn{12}{|c|}{ Analysis $^{1}$} \\
\hline & 1 & 2 & 3 & 4 & 5 & 6 & 7 & 8 & 9 & 10 & 11 & 12 \\
\hline & \multicolumn{12}{|c|}{ Major elements (weight percent) } \\
\hline $\mathrm{Al}$ & 1.886 & 2.397 & 2.606 & 2.51 & 2.73 & 1.904 & 2.102 & 1.9 & 2.099 & 2.489 & 2.214 & 2.352 \\
\hline $\mathrm{Ca}$ & 0.096 & 0.113 & 0.129 & 0.02 & 0.02 & 0.024 & 0.029 & 0.02 & 0.038 & 0.094 & 0.068 & 0.101 \\
\hline K & 0.45 & 0.57 & 0.61 & 1.24 & 0.86 & 0.58 & 0.77 & 0.77 & 0.78 & 0.93 & 0.82 & 0.82 \\
\hline $\mathrm{Mg}$ & 0.095 & 0.192 & 0.21 & 0.33 & 0.23 & 0.153 & 0.179 & 0.22 & 0.193 & 0.31 & 0.228 & 0.236 \\
\hline \multirow[t]{2}{*}{$\mathrm{Na}$} & 0.181 & 0.29 & 0.304 & 0.1 & 0.1 & 0.096 & 0.094 & 0.09 & 0.113 & 0.238 & 0.18 & 0.247 \\
\hline & \multicolumn{12}{|c|}{ Minor and trace elements (parts per million) } \\
\hline $\mathrm{Be}$ & $<1$ & $<1$ & $<1$ & 1 & $<1$ & $<1$ & $<1$ & $<1$ & $<1$ & 1 & $<1$ & $<1$ \\
\hline $\mathrm{Cd}(4.98)$ & $<2$ & $<2$ & $<2$ & 7 & 3 & $<2$ & $<2$ & 3 & $<2$ & $<2$ & $<2$ & $<2$ \\
\hline Co & 6 & 4 & 4 & 53 & 26 & 14 & 14 & 29 & 8 & 7 & 11 & 3 \\
\hline $\mathrm{Cr}(111)$ & 11 & 9 & 9 & 29 & 47 & 8 & 10 & 39 & 8 & 11 & 10 & 11 \\
\hline $\mathrm{Cu}$ & 5 & 12 & 13 & 418 & 451 & 264 & 355 & 471 & 149 & 144 & 234 & 75 \\
\hline $\mathrm{Hg}(1.06)$ & $<0.02$ & $<0.02$ & $<0.02$ & 0.09 & 0.05 & 0.04 & 0.04 & 0.04 & 0.04 & 0.06 & 0.05 & 0.04 \\
\hline Mn & 533 & 270 & 265 & 397 & 486 & 381 & 630 & 509 & 339 & 359 & 400 & 374 \\
\hline Mo & $<2$ & $<2$ & $<2$ & 21 & 6 & 4 & 6 & 6 & 4 & 3 & 4 & 3 \\
\hline
\end{tabular}

${ }^{1}$ Analysis key (Water sample site) —

1: MTHL1-1-SS: Music Branch background site (MTHL-1)

2: MTHL-9-SS: Tributary to Knights Branch downstream of Mitchell mine, background site (MTHL-9)

3: MTHL-9-SS-R: Replicate sample for MTHL-9-SS

4: 99VLZN7-SS1: Knights Branch at Valzinco mine near powerline

5: 99VLZN7-SS2: Knights Branch downstream at downstream end of fluvial tailings deposit 1(VLZN-3)

6: 02VLZN3-SS: Post-reclamation sample at same locality as 5

7: 02VLZN15- SS: Knights Branch at fluvial tailings deposit 2 (post-reclamation at Valzinco)

8: 99VLZN7-SS3: Knights Branch 1,200 m (4,000 ft) downstream from the bridge at the Valzinco mine (VLZN-11)

9: MTHL-4-SS: Post-reclamation sample at same locality as 8

10: MTHL-10-SS: Knights Branch at north end of fluvial tailings deposit 3

11: MTHL-8-SS: Knights Branch $30 \mathrm{~m}$ downstream from locality 10

12: MTHL5-SS: Knights Branch a few m downstream of fluvial tailings deposit 3 (MTHL-5) 

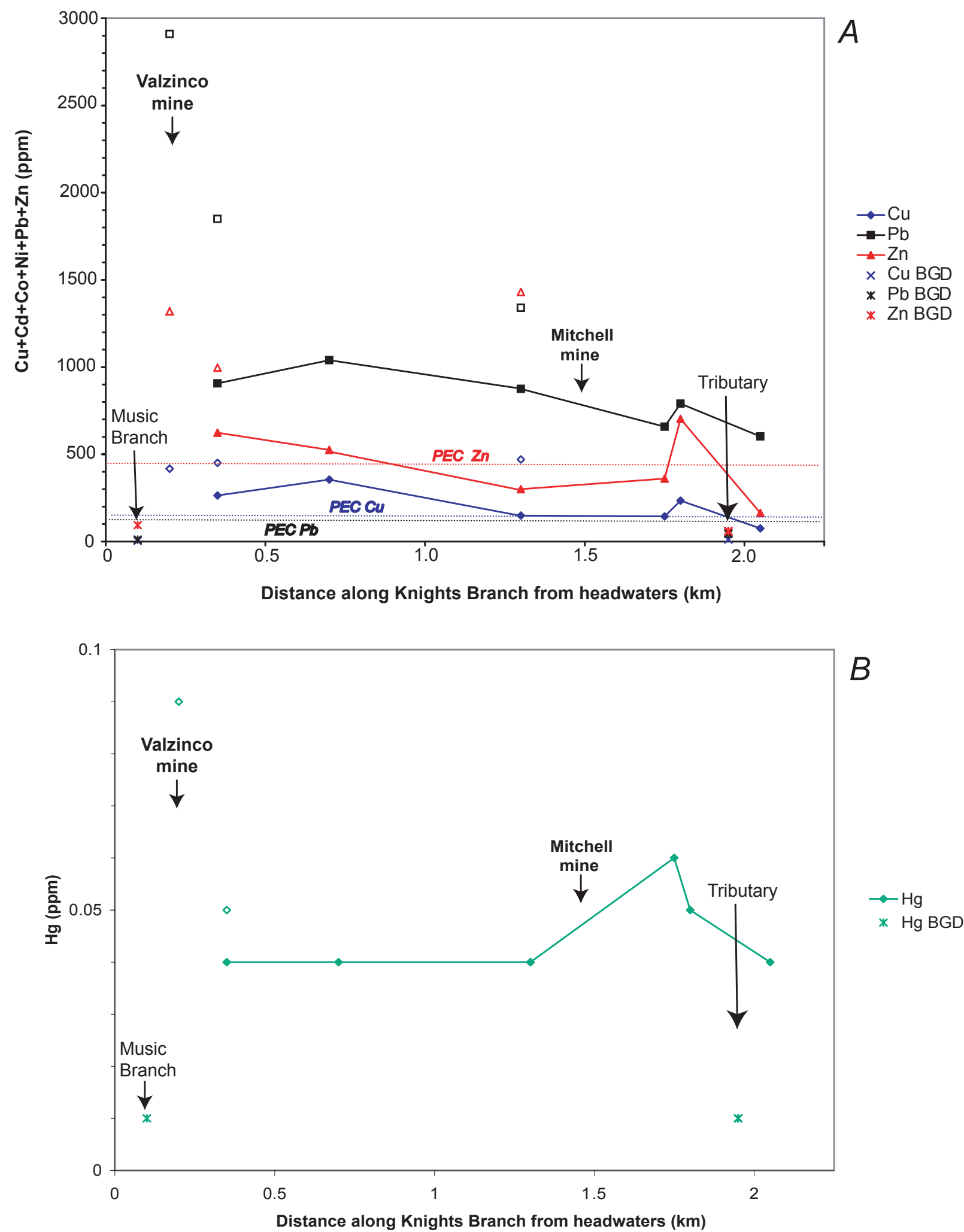

Figure 11. Stream sediment geochemistry along Knights Branch as a function of distance downstream from the headwaters. Background samples include Music Branch (in another watershed but plotted at $0.1 \mathrm{~km}$ for illustration) and an unnamed tributary that enters Knights Branch at fluvial deposit 3. Open symbols, samples collected in 1999 before reclamation. Solid symbols, samples collected in 2002 post-reclamation. $A$, Base metals. B, Mercury. Dotted lines show the probable effects concentrations (PEC) for zinc, copper, and lead. 
contained higher concentrations of base metals than the flocs (fig. $12 B$ shows the plot for lead). Three of the four sites used for the sediment accumulation experiment are quarterly water monitoring sites that were sampled at the beginning (February 7, 2001) and end (April 30, 2001) of the experiment (Seal and others, 2002). Stream $\mathrm{pH}$ was about $1 \mathrm{pH}$ unit higher at the end of the experiment; specific conductance decreased slightly. In sediments, $\mathrm{Pb}>\mathrm{Zn}>\mathrm{Cu}$ and base-metals concentrations increased during the course of the experiment (fig. $13 A$ ). In stream waters, $\mathrm{Zn}>\mathrm{Pb}>\mathrm{Cu}$ and dissolved base-metal concentration in April were lower than they were in February (fig. 13B). These data suggest that both water and sediment chemistry fluctuate during the course of a year. The increase in stream $\mathrm{pH}$ facilitated sorption of base metals onto bed sediments. Mean PEC quotients for the accumulated sediments are consistently higher than the quotients for the flocs sampled on February 7, 2001 (table 8). In some cases, the change is from a quotient less than 0.5 to one greater than 0.5 (correlated with a high incidence of toxicity by multiple components). In considering the overall health and restoration of the stream ecosystem, stream sediment quality may be as important as water quality because of its importance as habitat for benthic organisms. The data presented here indicate that improved water quality could be offset by degradation of sediment quality. Site-specific toxicity studies would be required to document the magnitude of these fluctuations.

\section{Weathering Experiments on Tailings}

The impact of dissolution of efflorescent sulfate minerals on water quality is well-documented (Dagenhart, 1980; Jambor and others, 2000). During site visits to Valzinco in all seasons over a 3-year period before reclamation, salts were sometimes ubiquitous on tailings and sometimes absent. Highest concentrations of dissolved metals in Knights Branch are associated with dry summer months (near base flow conditions) when dissolution of efflorescent salts during rain events and evaporative concentration control water quality (Seal and Hammarstrom, 2003). Hammarstrom and others (2004) showed that the Valzinco salts incorporated significant amounts of $\mathrm{Cd}$ and $\mathrm{Co}$ as well as $\mathrm{Al}, \mathrm{Fe}, \mathrm{Cu}, \mathrm{Pb}$, and $\mathrm{Zn}$.

The weathering experiment started on December 17, 1999, with freshly dug wet, black unoxidized tailings. Temperature and weather conditions were monitored several times a week. Temperatures during the first two weeks ranged from $-3^{\circ}$ to $20^{\circ} \mathrm{C}$, and the tailings were slightly to completely frozen. On January 3, 2000, the tailings were completely dry and coated with a thin layer of white salts (fig. 14). No precipitation (rain or snow) had occurred since December 22. The salts were identified by XRD as rozenite and gypsum. Minor amounts of zinc, manganese, magnesium, and aluminum were noted by SEM. On January 5, 2000, after $0.8 \mathrm{~cm}$ (0.3 in) of rain had fallen, the salts dissolved, and water collected in the experiment tray had a $\mathrm{pH}$ of 3.4. The experiment dried out again, and salts reformed within 24 hours following rain. The experiment was covered
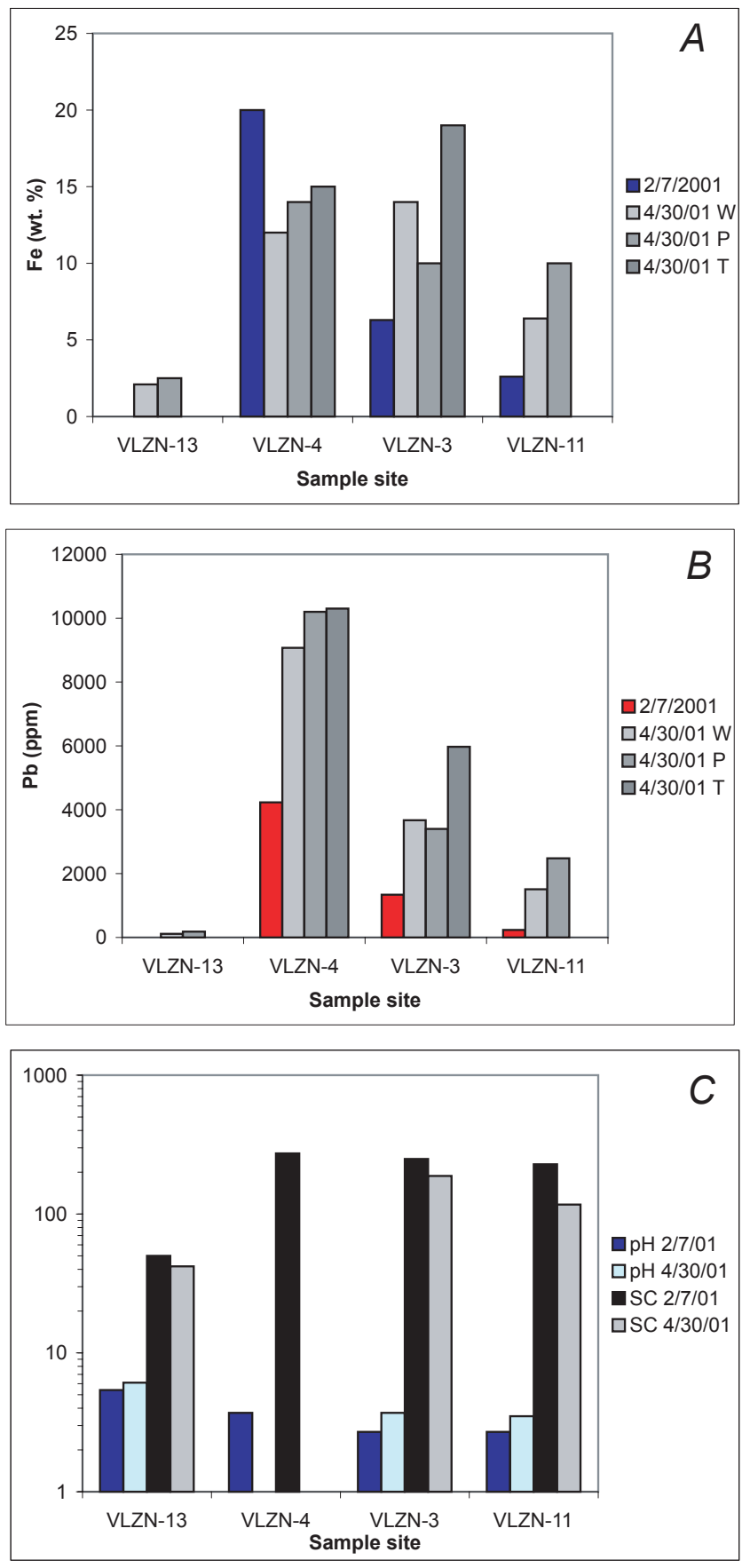

Figure 12. Sediment accumulation experiment. Bar chart showing range of iron $(A)$ and lead $(B)$ concentrations in floc (February 7,2001 ) and accumulated sediment retrieved on April 30, 2001 (W, wooden dowel; P, PVC pipe; T, ceramic tile). C, Field measurements of stream $\mathrm{pH}$ and specific conductance $(\mathrm{uS} / \mathrm{cm})$ at the experiment sites. VLZN-13, Knights Branch headwaters upstream of Valzinco mine; VLZN-4, Knights Branch flowing through Valzinco mine tailings; VLZN-3, Knights Branch at downstream end of fluvial tailings deposit 1; VLZN-11, Knights Branch 4,000 m downstream of the Valzinco mine (fig. 3). Water data from Seal and others (2002).

with snow for several weeks, after which it was terminated. At the end of the experiment, the tailings had not oxidized, but the 
Table 8. Selected geochemical data for Knights Branch accumulated sediments.

[Major elements analyzed by ICP-AES; P and other elements analyzed by ICP-MS; see Seal and others (2002) for water quality data corresponding to these sample sites; samples accumulated on submerged wooden dowels over 82 days indicated by $-\mathrm{A}$, other samples collected by syringe at water/sediment interface]

\begin{tabular}{|c|c|c|c|c|c|c|c|c|}
\hline Element & $\begin{array}{c}\text { VLZN-13-8A } \\
(04 / 30 / 01)\end{array}$ & $\begin{array}{l}\text { VLZN-4-8 } \\
(02 / 07 / 01)\end{array}$ & $\begin{array}{c}\text { VLZN-4-8A } \\
(04 / 30 / 01)\end{array}$ & $\begin{array}{c}\text { 01VLZN6 } \\
(02 / 070 / 01)\end{array}$ & $\begin{array}{l}\text { VLZN-3-8 } \\
(02 / 070 / 01)\end{array}$ & $\begin{array}{c}\text { VLZN-3-8A } \\
(04 / 30 / 01)\end{array}$ & $\begin{array}{l}\text { VLZN-11-8 } \\
(02 / 070 / 01)\end{array}$ & $\begin{array}{c}\text { VLZN-11-8A } \\
(04 / 30 / 01)\end{array}$ \\
\hline \multicolumn{9}{|c|}{ Major elements (weight percent) } \\
\hline $\mathrm{Al}$ & 1.6 & 2.5 & 2.8 & 4.6 & 2.6 & 1.8 & 2.5 & 2.4 \\
\hline $\mathrm{Ca}$ & 0.2 & 0.06 & 0.04 & 0.04 & 0.03 & 0.07 & 0.02 & 0.05 \\
\hline $\mathrm{Fe}$ & 2.1 & 20 & 12 & 17 & 6.3 & 14 & 2.6 & 6.4 \\
\hline K & 0.36 & 0.81 & 1.1 & 1.9 & 0.79 & 0.62 & 0.89 & 0.93 \\
\hline $\mathrm{Mg}$ & 0.1 & 0.3 & 0.4 & 0.5 & 0.2 & 0.22 & 0.1 & 0.23 \\
\hline $\mathrm{Na}$ & 0.2 & 0.1 & 0.07 & 0.1 & 0.2 & 0.07 & 0.1 & 0.1 \\
\hline $\mathrm{P}$ & 0.112 & 0.106 & 0.07 & 0.093 & 0.035 & 0.083 & 0.011 & 0.255 \\
\hline $\mathrm{Ti}$ & 0.65 & 0.1 & 0.1 & 0.2 & 0.35 & 0.23 & 0.38 & 0.37 \\
\hline \multicolumn{9}{|c|}{ Minor and trace elements (parts per million) } \\
\hline $\mathrm{Ag}$ & 0.2 & 5.4 & 7.8 & 17 & 1.5 & 4.3 & 0.34 & 1 \\
\hline As & 1.8 & 21 & 42 & 40 & 9.9 & 27 & 3.5 & 13 \\
\hline $\mathrm{Ba}$ & 169 & 141 & 186 & 319 & 218 & 126 & 346 & 238 \\
\hline $\mathrm{Be}$ & 0.6 & 1 & 1.3 & 1.9 & 0.9 & 0.7 & 0.8 & 1 \\
\hline $\mathrm{Cd}$ & 0.4 & 7.1 & 7.9 & 1.5 & 0.78 & 3.6 & 0.1 & 2.4 \\
\hline Co & 24 & 29 & 81 & 2.9 & 8.6 & 48 & 3.8 & 24 \\
\hline $\mathrm{Cr}$ & 14 & 44 & 14 & 28 & 22 & 13 & 18 & 14 \\
\hline $\mathrm{Cu}$ & 20 & 490 & 1,500 & 820 & 200 & 640 & 54 & 320 \\
\hline $\mathrm{Mn}$ & 2,800 & 460 & 860 & 360 & 300 & 580 & 260 & 520 \\
\hline Mo & 1.2 & 8.1 & 12 & 20 & 3.5 & 8.4 & 1.1 & 6.2 \\
\hline $\mathrm{Ni}$ & 4.2 & 19 & 11 & 4.2 & 7.8 & 6.9 & 4.7 & 5.4 \\
\hline $\mathrm{Pb}$ & 114 & 4,230 & 9,070 & 13,900 & 1,340 & 3,670 & 237 & 1,510 \\
\hline $\mathrm{Sb}$ & 0.2 & 6.7 & 11 & 18 & 2.8 & 5.7 & 0.7 & 3.4 \\
\hline $\mathrm{Se}$ & $<0.2$ & 1.8 & 1.8 & 2.5 & 0.4 & 1.4 & $<0.2$ & 0.4 \\
\hline $\mathrm{Sn}$ & 0.6 & 10 & 3.9 & 7.6 & 7.6 & 2.7 & 3.3 & 2.8 \\
\hline $\mathrm{Tl}$ & 0.3 & 0.9 & 1.3 & 2.5 & 0.7 & 0.7 & 0.5 & 0.7 \\
\hline $\mathrm{U}$ & 1.4 & 2.2 & 3.1 & 3.9 & 2 & 2.4 & 2.3 & 2.7 \\
\hline V & 28 & 90 & 80 & 132 & 43 & 51 & 28 & 46 \\
\hline W & 0.3 & 3.2 & 5.4 & 8.8 & 2.3 & 3.5 & 1.1 & 2.5 \\
\hline $\mathrm{Zn}$ & 120 & 3,530 & 4,310 & 1,370 & 524 & 2,080 & 180 & 1,190 \\
\hline \multicolumn{9}{|c|}{ Mean PEC quotient } \\
\hline & 0.2 & 6.7 & 13 & 17 & 2 & 5.6 & 0.4 & 2.5 \\
\hline \multicolumn{9}{|c|}{ Stream pH } \\
\hline & 6.1 & 3.7 & n.d. & 2.8 & 2.7 & 3.7 & 2.7 & 3.5 \\
\hline
\end{tabular}



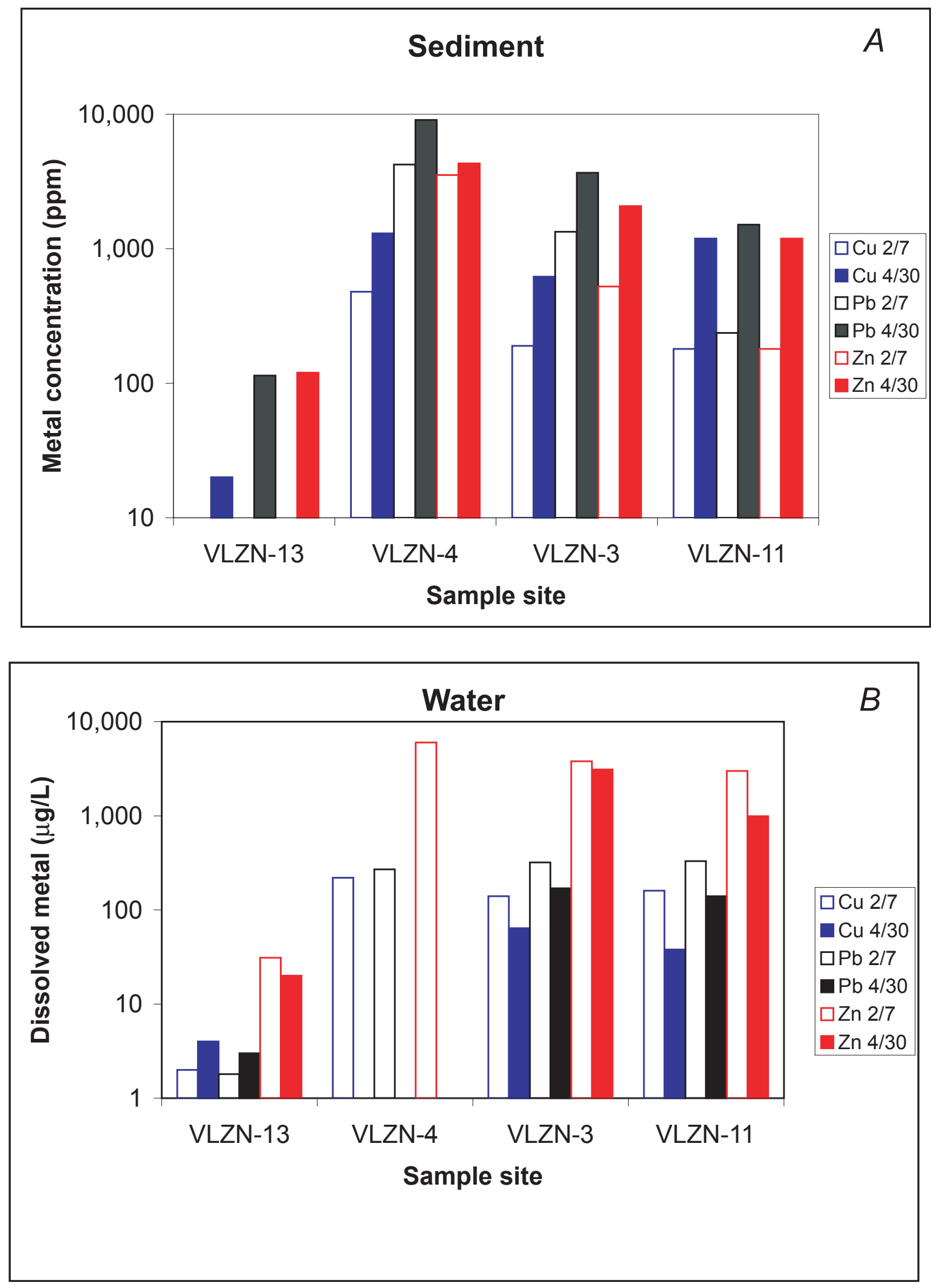

Figure 13. Bar charts showing the relative increase in base-metal concentrations in sediment and concomitant decreases in dissolved base-metal concentrations in stream water between February 7 and April 30, 2001. Same sample sites are as shown in figure 12. Water data from Seal and others (2002). 
surface developed a gray-green hue. The tailings surface developed a microscale topography, where salts coated topographic "highs." Similar features are noted on other mine-waste dumps where concentrated solutions that evaporate to form salts are wicked upward by capillary action (Hammarstrom and others, 2001). Field observations and the results of this experiment indicate that freshly exposed pyritic tailings such as those found at the Valzinco mine are highly reactive on short time scales. Site reclamation commonly involves excavation and relocation of tailings followed by capping. Exposure of pyritic tailings during this process has the potential to exacerbate acid-mine drainage by contributing metals and acidity from salt formation and dissolution to surface runoff and infiltrating groundwater. This situation does not appear to have been a problem at Valzinco, where the entire reclamation process was accomplished within a 1-year time frame.

\section{Summary}

- Pyrite-rich flotation tailings at the Valzinco mine contained up to $2 \mathrm{wt}$ percent lead, $2 \mathrm{wt}$ percent zinc, $0.2 \mathrm{wt}$ percent copper, and $8 \mathrm{wt}$ percent sulfur.

- No strongly acid-neutralizing minerals are present in tailings, mine waste, or host rock. Acid-base account- ing indicates that oxidized surface material as well as unoxidized tailings are net acid generating.

- Three fluvial tailings deposits downstream of the Valzinco mine along Knights Branch contain pyrite and elevated concentrations of base metals. Surface soil on the fluvial deposits exceeds EPA preliminary remediation goals only for lead in residential soils ( $>400 \mathrm{ppm} \mathrm{Pb}$ ).

- Pond sediment at the site of the Mitchell gold mine contains elevated mercury as well as base metals. Some samples exceed sediment-quality screening guidelines for mercury, copper, and zinc; all samples exceed guidelines for lead.

- Stream sediment quality in Knights Branch is impaired as much as $2 \mathrm{~km}$ downstream from the Valzinco mine site, mainly owing to elevated concentrations of lead.

- Sorption of metals on streambed precipitates is an important, $\mathrm{pH}$-dependent process that affects water quality.

- Efflorescent sulfate salts readily formed on the pyritic tailings at the Valzinco mine and intermittently contributed acid, minerals, and sulfate to Knights Branch.

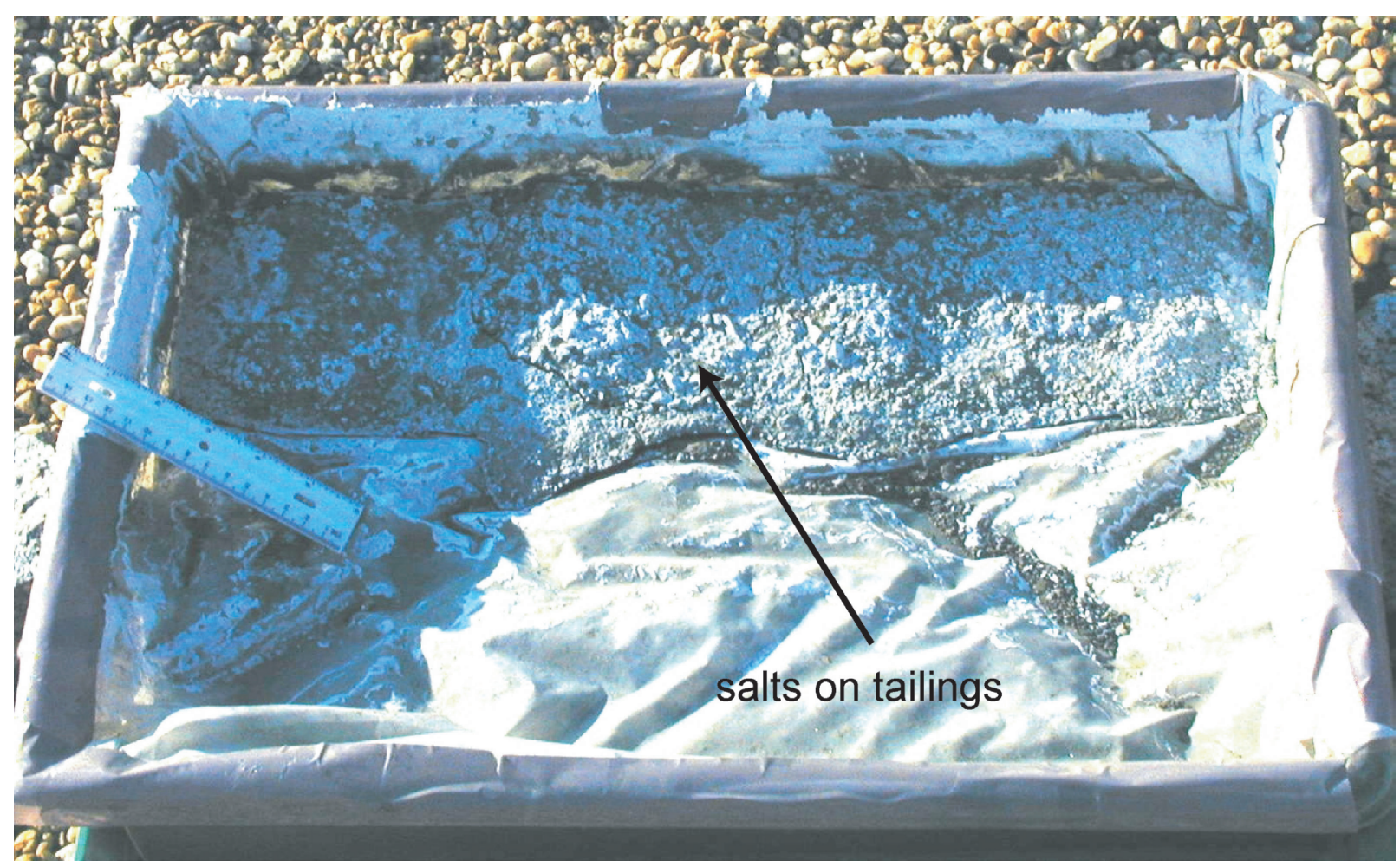

Figure 14. Photograph of the weathering experiment on Valzinco unoxidized tailings showing the uneven surface and thin crust of white efflorescent salts (rozenite and gypsum) that developed after 12 days of dry weather. 


\section{References}

Briggs, P.H., 2002, The determination of forty elements in geological and botanical samples by inductively coupled plasma-atomic mass spectrometry, in Taggart, J.E., Jr., Analytical methods for chemical analysis of geologic and other materials: U.S. Geological Survey Open-File Report 02-0223, Chapter G. Accessed 8/30/04 at:

http://pubs.usgs.gov/of/2002/ofr-02-0223/

G01fortyelementICP-AESsolid_M.pdf.

Briggs, P.H. and Meier, A.L., 2002, The determination of forty-two elements in geological materials by inductively coupled plasma-mass spectrometry, in Taggart, J.E., Jr., Analytical methods for chemical analysis of geologic and other materials: U.S. Geological Survey Open-File Report 02-0223, Chapter I. Accessed 8/30/04 at:

http://pubs.usgs.gov/of/2002/ofr-02-0223/

I20NAWQAPlus_M.pdf.

Cline, J.H., Watson, T.L., and Wright, F.J., 1921, A geologic map of the pyrite-gold belt in Louisa and Spotsylvania Counties, Virginia: Virginia Geological Survey, scale $1: 63,360$.

Dagenhart, T.V. Jr., 1980, The acid mine drainage of Contrary Creek, Louisa County, Virginia-Factors causing variations in stream water chemistry: M.S. Thesis, University of Virginia, Charlottesville.

Davis, A.M., Southworth, C.S., Reddy, J.E., and Schindler, J.S., 2001, Geologic Map Database of the Washington DC Area Featuring Data from Three 30 x 60 Minute Quadrangles-Frederick, Washington West, and Fredericksburg: U.S. Geological Survey Open-File Report 01-227.

Grosh, W.A., 1949, Investigation of Valzinco lead-zinc mine, Spotsylvania County, Virginia: U.S. Bureau of Mines Report of Investigations 4403, 7 p.

Hammarstrom, J.M., Seal, R.R., II, Meier, A.L., and Kornfeld, J.M., 2005, Secondary sulfate minerals associated with acid drainage in the eastern U.S.-Recycling of metals and acidity in surface environments: Chemical Geology, v. 215, p. 407-431.

Hammarstrom, J.M., Seal, R.R., II, Ouimette, A.P. and Foster, S.A., 2001, Sources of metals and acidity at the Elizabeth and Ely mines, Vermont-Geochemistry and mineralogy of solid mine waste and the role of secondary minerals in metal recycling, in Hammarstrom, J.M. and Seal, R.R., II, eds., Environmental geochemistry and mining history of massive sulfide deposits in the Vermont copper belt: Society of Economic Geologists, Field Trip Guidebook Series, v. 35, pt. II, p. 213-248.
Horton, J.W., Jr., Aleinikoff, J.N., Drake, A.A., Jr., and Fanning, C.M., 1998, Significance of Middle to Late Ordovician volcanic-arc rocks in the central Appalachian Piedmont, Maryland and Virginia: Geological Society of America Abstracts with Programs, v. 30, p. 125.

ICDD, 2002, Powder diffraction file release 2002, PDF-2: International Centre for Diffraction Data, Newton Square, Pa. Available from: http://www.icdd.com.

Jambor, J.L., 2003, Mine-waste mineralogy and mineralogical perspectives of acid-base accounting, in Jambor, J.L., Blowes, D.W., Ritchie, A.I.M. (eds.), Environmental aspects of mine wastes: Mineralogical Association of Canada Short Course vol. 31, 117-145.

Jambor, J.L., Nordstrom, D.K., Alpers, C.N., 2000. Metal-sulfate salts from sulfide mineral oxidation. in Alpers, C.N., Jambor, J.L., Nordstrom, D.K. (Eds.), Sulfate Minerals-Crystallography, Geochemistry, and Environmental Significance. Reviews in Mineralogy and Geochemistry, v. 40, p. 303-350.

Jambor, J.L., and Blowes, D.W., 1998, Theory and applications of mineralogy in environmental studies of sulfide-bearing mine waste, in Cabri, L.J., and Vaughn, D.J., (eds.), Modern approaches to ore and environmental mineralogy: Mineralogical Association of Canada Short Course, v. 27, p. 367-401.

Johnson, A.N., Hammarstrom, J.M., and Seal, R.R., II, 2000, Mineralogy and geochemistry of sulfidic mine waste at an abandoned $\mathrm{Pb}-\mathrm{Zn}$ mine; implications for acid-generating and acid-neutralizing potential: Geological Society of America Abstracts with Programs, v. 32, no. 7, p. 181.

MacDonald, D.D., Ingersoll, C.G., and Berger, T.A., 2000, Development and evaluation of consensus-based sediment quality guidelines for freshwater ecosystems: Archives of Environmental Contamination and Toxicology, v. 39, p. 20-31.

Mixon, R.B., Pavlides, L., Powars, D.S., Froelich, A.J., Weems, R.E., Schindler, J.S., Newell, W.L., Edwards, L.E., and Ward, L.W., 2000, Geologic map of the Fredericksburg 30 ' x 60' quadrangle, Virginia and Maryland: U.S. Geological Survey Geologic Investigations Series Map I-2607, scale $1: 100,000$.

MVTechnologies, Inc., 1998, Reclamation and acid drainage control at the Valzinco orphaned land project, MVTI Proposal No. VAMME1-070898 prepared for the Virginia Department of Mines, Minerals, and Energy, Charlottesville, Va., 7 p.

Pavlides, L, 1989, Early Paleozoic composite melange terrane, central Appalachian Piedmont, Virginia and Maryland; Its origin and tectonic history: Geological Society of America Special Paper 228, p. 135-193. 
Pavlides, L., Gair, J.E., and Cranford, S.L., 1982, Central Virginia volcanic-plutonic belt as a host for massive sulfide deposits: Economic Geology, v. 77, p. 233-272.

Poole, J.L., 1974, Notes on some abandoned copper, lead, and zinc mines in the Piedmont of Virginia: Virginia Minerals, v. 20,6 p.

Price, W.A., Morin, K., and Hutt, N., 1997, Guidelines for the prediction of acid rock drainage and metal leaching for mines in British Columbia, Part II-Recommended procedures for static and kinetic testing: Proceedings of the $4^{\text {th }}$ International Conference on Acid Rock Drainage, Vancouver, B.C., p. 15-30.

Seal, R.R., and Hammarstrom, J.M., 2003, Geoenviromental models of mineral deposits-Examples from massive sulfide and gold deposits, in Jambor, J.L., Blowes, D.W., and Ritchie, A.I.M., Environmental aspects of mine wastes: Mineralogical Association of Canada Short Course Series, v. 31, p. 11-50.

Seal, R.R., II, Johnson, A.N., Hammarstrom, J.M., and Meier, A.L., 2002, Geochemical characterization of drainage prior to reclamation at the abandoned Valzinco mine, Spotsylvania County, Virginia: U.S. Geological Survey Open-File Report 02-360, $36 \mathrm{p}$.

Seal, R.R., II, Hammarstrom, J.M., Foley, N.K., and Alpers, C.N., 2000, Geoenvironmental models for seafloor baseand precious-metal massive sulfide deposits: Proceedings from the Fifth International Conference on Acid Rock Drainage, Society of Mining, Metallurgy, and Exploration, Inc., Denver, Colo., v. 1, p. 151-160.

Seal, R.R., II, Piatak, N.M., Hammarstrom, J.M., Briggs, P.H., and Meier, A.L., in prep., Geochemical characterization of drainage in the vicinity of the abandoned Mitchell prospect, Spotsylvania County, Virginia: U.S. Geological Survey Report.
Shacklette, H.T., and Boerngen, J.G., 1984, Element concentrations in soils and other surficial materials of the conterminous United States: U.S. Geological Survey Professional Paper 1270, $105 \mathrm{p}$.

Sobeck, R.G., Jr., 2000, Mineral mine reclamation in Knights Branch, Spotsylvania County, Virginia (Project Design Concepts): Unpublished Report, Virginia Department of Mines, Minerals, and Energy, Division of Mineral Mining, Charlottesville, Va., $51 \mathrm{p}$.

Sobek, A.A., Schuller, W.A., Freeman, J.R., and Smith, R.M., 1978, Field and laboratory methods applicable to overburden and minesoils: EPA 600/2-78-054, 203 p.

Sweet, P.C., 1980, Gold in Virginia: Virginia Division of Mineral Resources Publication 19, 77 p.

Sweet, P.C., and Trimble, David, 1983, Virginia gold-resource data: Virginia Division of Mineral Resources Publication, v. 45, $196 \mathrm{p}$.

Taggart, J.E., Jr., 2002, Analytical methods for chemical analysis of geologic and other materials, U.S. Geological Survey: U.S. Geological Survey Open-File Report 02-0223.

U.S. Environmental Protection Agency, 1996, Water quality standards, Federally promulgated water quality standards: Federal Register, 40 CFR part 131, p. 611-640.

U.S. Environmental Protection Agency, 2004, Users' guide and background technical document for USEPA Region 9's Preliminary Remediation Goals (PRG) table: Accessed 12/7/04 at http://www.epa.gov/region09/waste/sfund/prg/ index.htm.

Watson, T.L., 1907, Mineral resources of Virginia: Lynchburg, Va., $618 \mathrm{p}$. 